\title{
A gênese textual da doutrina da educação das crianças no Tratado da Emenda do Intelecto de Espinosa
}

Professor doutor da Faculdade de Filosofia da Universidade Federal de Goiás (UFG)

\section{Resumo}

Meu objetivo no presente artigo é analisar o movimento argumentativo pelo qual Espinosa introduz, no proêmio do Tratado da Emenda do Intelecto, a expressão "Doctrina de puerorum Educatione". Embora não se trate de um conceito direta e detidamente desenvolvido por Espinosa, estimo ser possível reconstruir, com base na referida análise, a função de tal doutrina no interior do programa filosófico que aí se delineia. Através dessa reconstrução, pretendo defender que uma doutrina espinosana da educação das crianças deve necessariamente pautar-se pelo "princípio do acompanhamento do erro", de modo a exprimir, também no âmbito da pedagogia, o caráter radicalmente imanentista do sistema de Espinosa.

Palavras chave: educação; imanência; Emenda do Intelecto; acompanhamento do erro.

\begin{abstract}
My goal in this article is to analyze the argumentative steps by which Spinoza introduces, in the Tratise on the Emendation of the Intellect, the expression "Doctrina de puerorum Educatione". Although this is not a concept directly and carefully developed by Espinosa, it is possible, upon that analysis, to reconstruct it's function in the Tratise's prologue. By means of this reconstruction, I defend that such doctrine must necessarily be guided by the pedagogical principle of "to follow the error", consistent with the radically immanentist Espinosa's system.
\end{abstract}

Keywords: education; immanence; Emendation of the Intellect; to follow the error. 
Para Marta V. Alencar, Angel Pino

e Carmelita Felício,

três de meus bons encontros

entre filosofia e educação

\section{Os afazeres da felicidade: a ocorrência da expressão Doctrina de puerorum Educatione nos $§ 14$ e 15 do Tratado da Emenda do Intelecto}

É no décimo quinto parágrafo do Tratado da Emenda 1 que Espinosa se refere, de forma vaga e meramente alusiva, a uma "Doutrina da Educação das crianças". Não é meu objetivo aqui tentar reconstituir qual poderia ser o conteúdo preciso de tal doutrina, mas tão somente determinar sua função na economia conceitual dos parágrafos que compõem o chamado prólogo ou proêmio dessa obra de Espinosa ( $\S \S 1$ a 18 ). É apenas com base nessa análise preliminar do texto que, finalmente, procurarei determinar também algumas características do que se poderia chamar, grosso modo, de "espírito" ou "caráter" da doutrina.

É necessário, portanto, que, antes de mais nada, seja posta em consideração a unidade textual cuja reconstrução argumentativa será o caso de empreender ${ }^{2}$. Mantendo grande proximidade com o texto latino, uma

\footnotetext{
${ }^{1}$ Para fins de concisão, doravante usarei, como equivalente do título completo do tratado espinosano, a forma Tratado da Emenda ou simplesmente a sigla para o título latino: TIE (Tractatus de Intellectus Emendatione). Quanto às razões que sustentam a preferência por emenda, ao invés das alternativas mais usuais, correção ou reforma, isto será comentado mais adiante, através do próprio desenvolvimento do assunto no corpo do texto. A numeração dos parágrafos do TIE seguirá sempre aquela introduzida por Bruder, em 1843, e indicada em atuais edições de referência, tais como a de Bernard Rousset (EsPINOSA, 1992) aqui preferencialmente consultada. Ao longo deste artigo, empregarei a primeira pessoa do singular de preferência às formas do impessoal ou do plural majestático. $\mathrm{O}$ uso do plural majestático criaria confusão com as formulações em que desejo intencionalmente implicar o leitor (e.g. "podemos compreender que", "já vimos que", etc.). Considerações filosóficas contra o uso impensado e burocrático do impessoal podem ser hauridas do conhecido §27 de Ser e Tempo, de Heidegger (1988, pp. 178-183).

$\mathrm{O}$ uso da primeira pessoa do singular explicita que tais ou quais asserções são feitas por conta e risco de quem as enuncia, sendo, pois, um índice de responsabilidade intelectual. Isso, naturalmente, não significa uma recusa de todo e qualquer uso do impessoal, mas apenas de seu uso de forma automática e impensada.

${ }^{2}$ Em tempo: recomendo, desde já, que o leitor, antes de prosseguir neste artigo, realize
}

Filosofia e Educação - ISSN 1984-9605 - Volume 5, Número 1

Abril - Setembro de 2013 
tradução razoável para o mencionado parágrafo 15 do Tratado da Emenda

poderia ser a seguinte:

Ademais (Porro), é preciso dedicar trabalho (danda est opera) à filosofia moral (morali philosophiae), como também (ut et) à doutrina da educação das crianças (Doctrinae de puerorum Educatione); e porque (et quia) a saúde (valetudo) não é um meio pequeno (non parvum est medium) para que tal fim (ad hunc finem) seja conseguido (assequendum), deve ser organizada (concinnanda est) a medicina inteira (integra medicina); e porque (et quia) pela arte (arte) muitas coisas que são difíceis (multa, quae difficilia sunt) são tornadas fáceis (facilia redduntur), e por meio dela (ea) podemos lucrar na vida (in vita lucrari possumus) também muito de tempo e de comodidade (multumque temporis et commoditatis), por isso (ideo), a mecânica (mechanica) de nenhum modo deve ser desprezada (nullo modo est contemnenda)

Em primeiro lugar, deve-se notar que a palavra inicial do parágrafo, o advérbio "ademais" (porro), já indica o tipo de articulação do excerto com seu contexto englobante. Trata-se de uma articulação que qualifica como suplementares os dados por ela introduzidos. Algo que acabara de ser estabelecido nas linhas precedentes - possuindo, portanto, uma caracterização mínima já constituída - passa agora a receber um novo conjunto de atribuições, agrupadas entre si e diferentes das primeiras, mas dependentes de que estas já houvessem sido apresentadas.

Isso é digno de nota porque, no parágrafo imediatamente anterior (§14), Espinosa estabelecera nada menos que o fim a que se dedica todo o

uma primeira leitura dos parágrafos 1 a 18 do TIE, para que possa acompanhar os movimentos não lineares da análise que será aqui realizada. Duas boas traduções brasileiras desse texto são as de Lívio Teixeira (EsPINOSA, 1966) e Carlos Lopes Matos (ESPINOSA, 1979). Não obstante a boa qualidade de tais publicações, todas as traduções dos excertos de Espinosa aqui citados são de minha autoria, salvo quando houver indicações em contrário. $\mathrm{O}$ uso de colchetes indica incisões ou alterações mais significativas exigidas por nosso idioma. O texto latino consultado para a tradução dos excertos do TIE foi o estabelecido por Rousset (ESPINOSA, 1992), e para os excertos de outras obras foi usada a edição Gebhardt (EsPINOSA, 1972). Ciente de que a inserção, depois de cada seguimento traduzido, de seu equivalente latino entre parêntesis, torna incômoda a leitura, mantenho, porém, este recurso, não só porque já dispomos dessas outras traduções - mais elegantes e fluentes — do mesmo texto, mas, principalmente, porque o tipo de reconstrução aqui pretendida supõe estrita observância às exigências lexicais e sintáticas das formulações originais de nosso filósofo, que devem, portanto, ser disponibilizadas.

Filosofia e Educação - ISSN 1984-9605 - Volume 5, Número 1

Abril - Setembro de 2013 
Tratado da Emenda e, em última análise, a inteira filosofia espinosana, qual seja: a suprema felicidade (summa felicitas ou summa ac continua laetitia, nos termos dos parágrafos iniciais do texto ${ }^{3}$ ). O que, porém, desejo destacar no passo em foco é que - depois de um intrincado percurso - o parágrafo 14 retoma essa ideia de felicidade, mas desta vez em termos de fruição de certa natureza humana. É isso que já se encontra estabelecido para que se possa, em seguida, falar, entre outras atividades, de uma doutrina da educação das crianças. Embora o termo natureza denote aproximadamente o mesmo que o termo essência, ele conota, tanto na tradição escolástica quanto no sistema espinosano, a essência entendida mais precisamente como operação ou atividade própria da coisa. E particularmente na filosofia espinosana, ter certa natureza é ser uma essência actuosa, que resulta de atividades constitutivas de ordem mais elementar e que, ao mesmo tempo, origina ou toma parte da constituição de atividades de ordem superior ( $C f$. Ética I prop. 36). A felicidade é uma atividade essencial, ou, o que é o mesmo, uma forma de $\operatorname{ser}^{4}$. E Espinosa acrescenta: uma forma de ser que só se perfaz coletivamente. Em suas palavras:

aqui está (Hic est), então (itaque), o fim ao qual tendo (finis, ad quem tendo), a saber (scilicet):

(a) adquirir tal natureza (talem naturam acquirere), e (et)

(b) me esforçar (conari) para que muitos a adquiram comigo (ut multi mecum eam acquirant). ${ }^{5}$

\footnotetext{
3 "Suprema felicidade" ou "suprema e contínua alegria". Há, certamente, diferenças entre alegria (laetitia) e felicidade (felicitas) que podem ser exploradas no restante do sistema espinosano, mas, ao menos no presente contexto, cumpre observar que Espinosa parece aceitar algum grau de equivalência entre esses vocábulos, uma vez que, nos $\S \S 1$ e 2 , os emprega de modo indistinto.

${ }^{4} \mathrm{O}$ uso de forma, na acepção aqui pretendida, encontra amparo na ideia de forma do indivíduo, tal como esta é trabalhada na chamada "pequena física" da Ética (os axiomas, lemas e definições que se seguem ao escólio da prop. 13 de Ética II). No âmbito humano, a autoconservação dinâmica da forma individual — aí implicadas as relações de inteiração com outros indivíduos - pode ser dita uma forma de vida, que compõe o significado do conceito de institutum empregado nos $\S \S 3$ e 6 TIE. Sobre o termo institutum, confira-se a nota 14 infra.

${ }^{5}$ TIE §14. É minha a introdução das letras que explicitam as duas partes do fim, bem como a rediagramação do excerto. Usarei esse recurso, ao longo da presente seção, para enumerar as partes dos $\S \S 14$ e 15.
}

Filosofia e Educação - ISSN 1984-9605 - Volume 5, Número 1

Abril - Setembro de 2013 
Não seria incorreto admitir, por exemplo, que esse esforço (conari) coletivizante (ut multi mecum) está não só verbal mas também conceitualmente ligado à conhecida noção espinosana de conatus (a própria essência de uma coisa, entendida como o esforço pelo qual ela se esforça por perseverar em seu ser $\left.{ }^{6}\right)$. O que, então, Espinosa estaria sugerindo, já no Tratado da Emenda, é que faz parte desse esforço essencial o esforço para a aquisição conjunta de uma mesma natureza pela maior quantidade possível de outros seres congêneres (outros homens, no caso). E uma vez que o que é adquirido é uma natureza, não há nada que a impeça de ser adquirida e fruída por muitos ao mesmo tempo, o que não apenas permite mas até mesmo exige uma tendência ontológica para que cada coisa se esforce por formar e integrar sistemas dinâmicos cada vez mais amplos, complexos e ao mesmo tempo estáveis. Toda coisa trabalha por um mundo em que mais e mais elementos lhe sejam consistentes e confirmem, nessa mesma medida, a necessidade de sua essência e de sua existência no sistema da realidade. O conatus, portanto, não pode ser tomado como esforço conservador "fechado", mas sim como um perseverar em expansão, pois o conservar-se de algo em seu ser já seria, por si só, articular-se com outros e ampliar-se (em última instância, tomando parte ativa na estruturação do real, com ele co-laborando). Isso se verifica na seguinte explicitação, ainda no parágrafo 14, da interdependência entre as supracitadas partes (a) e (b) do fim proposto:

também (etiam) é de minha felicidade (de mea felicitate est) dedicar trabalho (operam dare) para que muitos outros (ut alii multi) entendam o mesmo que eu (intelligant idem atque ego), para que (ut) seus intelectos e desejos (eorum intellectus et cupiditas) convenham inteiramente (prorsus conveniant) com meu intelecto e desejo (cum meo intellectu et cupiditate).

\footnotetext{
${ }^{6} \mathrm{O}$ pleonasmo "esforço pelo qual se esforça" é do próprio Espinosa: "O esforço pelo qual (Conatus quo) cada coisa (unaquaeque res) se esforça (conatur) a perseverar em seu ser (in suo esse perseverare),nada é além da própria (nihil est praeter ipsius) essência atual da coisa (rei actualem essentiam)" Ética. III prop. 7.
}

Filosofia e Educação - ISSN 1984-9605 - Volume 5, Número 1

Abril - Setembro de 2013 
Ora, é precisamente então que nosso filósofo passa a apresentar dois grupos de "tarefas" derivadas, que são necessárias (necesse est) para que se faça (utque fiat) a fruição coletiva e concordante de certa natureza humana ${ }^{8}$. O primeiro grupo contém duas tarefas:

(c) entender da natureza (de natura intelligere) apenas o quanto baste (tantum quantum sufficit) para que seja adquirida (ad acquirendam) tal natureza (talem naturam);

(d) formar tal sociedade (formare talem societatem), a qual deve ser desejada (qualis est desideranda), para que (ut) tanto muitos (quamplurimi) quanto segura e facilimamente (quam facillime, et secure) cheguem a isso (eo perveniant) [sc. ao fim proposto: adquirir aquela natureza].

E o segundo grupo, subordinado a este primeiro, é precisamente aquele apresentado pelo nosso parágrafo 15 e contém as quatro tarefas já citadas:

(e) dedicar trabalho à filosofia moral;

(f) dedicar trabalho à doutrina da educação das crianças;

(g) organizar a medicina;

(h) dar atenção à arte mecânica.

Porque o fim almejado é uma natureza, uma forma ativa de ser, os meios que condicionam sua obtenção também são atividades. Dentre elas, o cuidado com doutrina da educação das crianças — alinhado estreitamente ao cuidado com a filosofia moral pela própria sintaxe do texto de Espinosa - constitui tarefa particularmente estratégica na harmonização coletiva dos intelectos e dos desejos. A medicina e a mecânica, por seu turno, parecem ser trabalhos de harmonização no âmbito corporal, lidando com os corpos humanos individuais e coletivos ${ }^{9}$ e suas interações com os demais corpos do mundo físico. Aliás, estas duas últimas ciências atendem perfeitamente à exigência - expressa no ponto (c) - de um conhecimento da natureza

${ }^{7} \mathrm{O}$ termo "tarefa" encontra apoio na expressão operam dare, que traduzi, de modo bastante literal e intencionalmente forçado, como "dedicar trabalho a". A doutrina da educação das crianças tem, pois, esse estatuto de uma tarefa, um afazer.

8 Tal natureza ainda não foi aqui caracterizada, em virtude da ordem reversa da reconstrução, mas será comentada com maiores detalhes logo mais.

9 É perfeitamente possível identificar no sistema espinosano um lugar para a saúde coletiva e até mesmo para a saúde pública (Cf. REZENDE 2010).

Filosofia e Educação - ISSN 1984-9605 - Volume 5, Número 1

Abril - Setembro de 2013 
guiado pela aplicação (o que fica especialmente claro no caso da mecânica, cujo estatuto de técnica (ars) é explicitado pelo narrador).

Entretanto, na nota $d$ do parágrafo 14, Espinosa afirma não estar preocupado, nesse momento, em ordenar e encadear "as ciências necessárias ao nosso escopo", mas apenas em enumerá-las ${ }^{10}$. Cabe, destarte, perguntar: para além do fato de que cada uma dessas tarefas derivadas (e-h) vem cumprir a missão - expressa no ponto $(\mathrm{d})$ - de garantir a quantidade, a facilidade e a segurança da chegada e manutenção dos homens na vida social almejada, em que consistiria seu agrupamento no interior do movimento argumentativo do proêmio? Bernard Rousset (ESPINOSA, 1992, p 170) corretamente observa que essa nota vem esclarecer que não se trata aqui do "encadeamento lógico" das ciências apresentadas no parágrafo 15 (diversamente, por exemplo, do famoso modelo da árvore cartesiana para a unidade do conhecimento). Todavia, indo mais longe, o comentador acrescenta, no mesmo passo, que "na lista oferecida, não há efetivamente qualquer ordem genética, qualquer liame dedutivo, qualquer transição construtiva encadeando as disciplinas umas às outras”. Ora, a meu ver Rousset exagera na ideia de falta de unidade nessa enumeração. É certo que Espinosa não pretende aqui formar um sistema de todas as ciências, em estilo pós-kantiano; mas isso não exclui - ao contrário, reforça - nosso direito de perguntar: de onde provém, então, a escolha precisa dessas atividades, dentre as quais a doutrina da educação das crianças? Qual o sentido de seu agrupamento? Como ele se gera?

Bem, a resposta que eu gostaria de defender é que esse agrupamento corresponde a uma recuperação e ressignificação, num plano conceitual mais elaborado, dos mesmíssimos objetos de desejo que, num primeiro momento da narrativa, eram apresentados como impedimentos para a aquisição da felicidade. E se isso é verdade, será possível atribuir à doutrina

${ }^{10}$ TIE $\$ 14$, nota $d$ : "Note que aqui (Nota, quod hic) cuido somente (tantum curo) de enumerar as ciências (enumerare scientias) necessárias ao nosso escopo (ad nostrum scopum necessarias), sendo lícito (licet) que eu não venha a atentar à sua série (ad earum seriem non attendam)".

Filosofia e Educação - ISSN 1984-9605 - Volume 5, Número 1

Abril - Setembro de 2013 
espinosana da educação das crianças um caráter ou espírito marcado por essa não eliminação de elementos eventualmente perniciosos. Mais ainda: essa não eliminação, que recupera e ressignifica o aparentemente deletério, estaria no cerne da própria noção de emendatio, conferindo-lhe, no plano epistemológico do Tratado que ela intitula, não o caráter de uma pura correção ou reforma, mas sim de um 'acompanhamento do erro', necessário à plena integração da mente com a verdade.

Para defender tal posição, será preciso rearticular os parágrafos $14 \mathrm{e}$ 15 com o restante do proêmio do Tratado da Emenda, ligando-os tanto ao que os antecede ( $\S 1-13)$ quanto ao que os sucede $(\S \S 16-18)$.

\title{
II - Bens ordinários, bens verdadeiros e bem supremo (§§ 1-13)
}

\section{II.1) O parágrafo 1}

Desde seu começo, essa obra de Espinosa se configura como uma busca, uma inquirição, como podemos ler já no parágrafo 1 :

\begin{abstract}
decidi finalmente inquirir (constitui tandem inquirere) se haveria (an daretur) algo (aliquid) que fosse um verdadeiro bem (quod esset verum bonum) e comunicável de si (et sui communicabile), e pelo qual apenas (et a quo solo), rejeitados todos os demais (reiectis ceteris omnibus), o ânimo fosse afetado (animus afficeretur); mais ainda (imo), se haveria algo (an aliquid daretur), que uma vez descoberto e adquirido (quo invento et acquisito), eu fruísse uma alegria (fruerer laetitia) contínua e suprema (continua ac summa) eternamente (in aeternum).
\end{abstract}

É esse algo procurado, ainda abstrato — um mero aliquid, nesse início da narrativa espinosana —, que vai, desde então, passo a passo ganhando determinações e, com isso, construindo o proêmio. Diferentemente do que já estará disponível nos parágrafos 14 e 15, tudo que se sabe sobre o fim nesse momento inicial é que ele pode ser chamado de "verdadeiro bem" e que possui as seguintes especificações mínimas:

(i) é comunicável;

(ii) somente ele deve afetar o ânimo, ao passo que os demais bens devem ser rejeitados;

Filosofia e Educação - ISSN 1984-9605 - Volume 5, Número 1

Abril - Setembro de 2013 
(iii) sua descoberta, somada à sua aquisição, será a fruição de uma alegria contínua, suprema e eterna.

Estas são as características do buscado enquanto buscado, ou seja, aquilo que é necessário saber a seu respeito para que se possa, pelo menos, procurá-lo e reconhecê-lo caso ele seja encontrado. Mas se, por um lado, quem procura algo já deve saber o que procura, por outro, não deve sabê-lo — sob pena de vã redundância - como quem já o houvesse encontrado. O que é preciso que se possua do fim no começo não pode ser o mesmo que se há de possuir do fim no fim. Nesse início, o "verdadeiro bem” é apenas um vazio delimitado por essas três características, as quais, portanto, também permanecem insuficientemente compreendidas ${ }^{11}$. Porque não se sabe $o$ conteúdo do "verdadeiro bem", tampouco é possível saber o que seria (i) sua referida comunicabilidade, ou (ii) sua exclusividade em detrimento dos demais, e muito menos (iii) como se relacionam sua descoberta e sua aquisição.

Isso é relevante porque, ao longo da narrativa do proêmio, a superação das dificuldades que vão sendo encontradas depende, em grande medida, de uma mudança progressiva nesta compreensão do que é que estava sendo procurado (uma mutação conceitual, uma revisão dessas três especificações preliminares, à luz do desenvolvimento da inquirição). Quer dizer, as aporias na aquisição (acquisitio) do "verdadeiro bem" vão se resolvendo em função do bom andamento de sua descoberta (inventio), o que já corresponde justamente a um aprimoramento na compreensão do ponto (iii): dependendo de como se conceba o "verdadeiro bem", ele poderá ser ou não ser adquirido.

\section{II.2) Os parágrafos 2 a 5}

Quanto às insuficiências iniciais no entendimento do ponto (ii), isto é, na

\footnotetext{
11 Cf. TIE §95: “as propriedades das coisas (proprietates rerum) não são inteligidas (non intelliguntur) enquanto suas essências são ignoradas (quamdiu earum essentiae ignorantur)"
}

Filosofia e Educação - ISSN 1984-9605 - Volume 5, Número 1

Abril - Setembro de 2013 
compreensão ainda abstrata da exclusividade do "verdadeiro bem", elas estão no centro dessas dificuldades enfrentadas ao longo do proêmio. Com efeito, se o narrador, no parágrafo 2 , sente necessidade de dizer enfaticamente que foi apenas ao final (tandem) de um processo que ele se pôs a buscar o "verdadeiro bem", isso se deu precisamente porque, à primeira vista (primo intuitu), lhe pareceu precipitado ou inconsulto (videbatur inconsultum) rejeitar — em nome de um "verdadeiro bem" que ainda não fora sequer descoberto — os demais bens já disponíveis e as vantagens e comodidades (commoda) que eles já propiciavam dentro do modo de vida em que o filósofo já se encontrava ${ }^{12}$. Antes de partir em busca do "verdadeiro bem", foi necessário refletir muito e ponderar a fundo sobre como somente (solum) ele haveria de afetar o ânimo e sobre como todos os demais bens haveriam de ser rejeitados (rejectis). Em verdade - veremos —, o desenlace decisivo consistirá justamente em compreender que não há como rejeitar de forma absoluta qualquer um desses bens ordinários, mas apenas como modificar nosso modo de relação com eles, rejeitando o mal que nos faziam mas não eles próprios como partes internas à dinâmica da

12 É importante observar que, se os bens ordinários são certos em sua disponibilidade ou consecução (sua consecutione), isto não significa que os possuímos ou obtemos com segurança ou facilidade, isto é, como se os dominássemos. Examinando o modo espontâneo com que os homens, segundo o TIE, fruem da vida comum, Pierre-François Moreau (1994, p 78-79) caracteriza muito bem em que consiste a certeza dos bens ordinários: "eles estão ao alcance da mão e eles fornecem vantagens [commoda]. É sua acessibilidade e sua visível eficácia, não sua posse imediata que constitui sua certeza". Tal certeza é própria ao que é "déjà là", ou seja, é uma prerrogativa do "primeiro ocupante", do "familiar", do "disponível", do que "está comigo antes que eu comece a refletir". No interior do sistema da vida comum - que Moreau chama de "mundo do que está dado" despende-se, porém, muito esforço para aquisição e conservação de seus bens próprios, e isso se passa justamente porque há também muito risco de fracasso e de perda. Mas, esse mundo como um todo não é adquirido: ele se nos antepõe como encontrado. Ele é — num vocabulário clássico e que revela o fundo epistemológico do que está em jogo — o que é primeiro para nós, cronológica ou existencialmente, mas não na ordem do ser. É isso o que ressalta da própria leitura de Moreau, quando este diz, por exemplo, que a vida comum "é o que não tem necessidade de mudança para estar aí; só aquele que quer outra coisa é que deve mudar (...) Ela [sc. a vida comum] é incontornável; ela não é uma escolha de vida; pode haver talvez uma decisão de deixá-la; mas não há decisão de nela entrar; ela está aí desde que nós estamos aí; ela é a forma espontânea de nossa condição (...). Isso não quer dizer que ela seja o fundamento do resto; mas ela é o dado primeiro a partir do qual nós alcançaremos o fundamento" (MOREAU, 1994, p 107-108 - itálicos e incisos meus).

Filosofia e Educação - ISSN 1984-9605 - Volume 5, Número 1

Abril - Setembro de 2013 
vida.

Numa tradição que remonta, pelo menos, à Ética Nicomachea de Aristóteles, Espinosa afirma que "é lícito inferir (colligere licet), a partir do que os homens fazem (ex eorum operibus)", que tais bens ordinários se reduzem basicamente aos três seguintes: honra (honor), riqueza (divis) e prazer (libido). E a dificuldade - apenas ao final da qual foi possível efetivamente colocar-se em busca de outro modo de vida - era que, se não houvesse outra felicidade além da que é proporcionada por esses bens ordinários, a inquirição exigiria que dela o narrador se abstivesse ${ }^{13}$. Mas se, ao invés disso, a felicidade não se encontrasse na posse de tais bens, dela também o narrador ver-se-ia privado, caso não se lançasse à busca do “verdadeiro bem”. Não parecia possível, portanto, ter as duas coisas. No parágrafo 3, Espinosa descreve nos seguintes termos essa impossibilidade, para um mesmo homem, de buscar, ao mesmo tempo, os bens ordinários e o verdadeiro:

Revolvia, portanto, em meu ânimo (Volvebam igitur animo) se acaso não seria possível (an forte esset possibile) chegar a uma nova instituição [de vida] (pervenire ad novum institutum), ou pelo menos (aut saltem) à certeza da mesma (ad ipsius certitudinem), sem que fosse mudada (licet non mutaretur) a ordem e a instituição (ordo et institutum) de minha vida comum (commune vitae meae), o que muitas vezes tentei (quod saepe tentavi) frustradamente (frustra) ${ }^{14}$

Essa é a primeira e mais abstrata forma da exclusividade do

${ }^{13} T I E$ §2: "eu era forçado a me abster (cogebar abstinere) de procurar essas [coisas] (ab iis quaerendis) se quisesse seriamente (si seriam vellem) dedicar trabalho (operam dare) a alguma outra coisa nova (rei alii novae)"

${ }^{14}$ TIE §3. No dicionário Latim-Inglês de Lewis \& Short, Oxford, (in: http://www.perseus.tufts.edu), registram-se os seguintes significados para institutum: "um propósito, intenção, desígnio; um arranjo ou plano; modo de vida, hábitos, práticas, maneiras; uma regulamentação". O verbo volvo, -ere, por sua vez, indica, concretamente, volver, revolver, voltar em giro, girar, rolar, verter, despejar, etc. Abstratamente e em sentido figurado, significa pensar e repensar, considerar a mesma coisa muitas vezes, conotando, pois, também nesse registro, um movimento circular, repetitivo. No contexto de seu uso por Espinosa, cabe interpretar o termo como conotando uma repetição sem condições internas, ou próprias, de dar fím a si mesma. Tal interpretação, ao menos no que se refere ao texto espinosano, é reforçada pelo advérbio forte, ou seja, pela maneira fortuita com que uma conclusão apresentar-se-ia caso isso de fato viesse a ocorrer por meio desse expediente, ou seja, por meio do "volver em ânimo".

Filosofia e Educação - ISSN 1984-9605 - Volume 5, Número 1

Abril - Setembro de 2013 
"verdadeiro bem": a exclusão recíproca, a disjunção total, ou ele ou tudo mais! Mas, cabe perguntar: por quê? O que torna necessariamente frustradas essas primeiras tentativas de compatibilização? Ora, responde o parágrafo 3, essas tentativas fracassam porque os bens ordinários "são estimados como bens supremos" (tamquam summum bonum aestimantur), e “arrastam a mente em múltiplas direções (distrahitur mens)" $)^{15}$ a tal ponto (adeo) que ela mal pode (ut minime possit) pensar sobre outro bem (de alio aliquo bono cogitare)". Quer dizer, era impossível ter as duas coisas porque, ironicamente, esses bens ordinários é que exigiam exclusividade e rejeição de tudo mais, ao menos quando tomados como bens supremos. E, para quem puder atinar com a já mencionada matriz aristotélica desse texto de Espinosa, será fácil antecipar que tomar algo como summum bonum equivale a não desejá-lo em vista de outra coisa (di'heteron), como um fim subalterno, um meio, estimando-o, antes, por si mesmo (di'auto), como um fim último numa cadeia de ações (Cf. Aristóteles, Ética a Nicômaco, 1094a1 $-1094 b 13)$.

Ou seja, só era impossível uma solução compatibilista por que, desejados por si mesmos, os bens ordinários se fechavam à alteridade (minime de alio) e se tornavam, por assim dizer, obsediantes ${ }^{16}$ :

- §4: pelo prazer "o ânimo é suspenso (suspenditur animus) (...) maximamente (maxime) [a ponto de] não pensar em outra [coisa] (impeditur ne de alio cogitet)";

- $\$ 5$ a honra "é suposta (supponitur) (...) ser sempre boa por si (semper bonum esse per se)";

- $\S 4$ : e a riqueza é frequentemente buscada "por si" (propter se).

\footnotetext{
${ }^{15}$ Adoto esta tradução de distraho, ao invés da mais natural, "distrair", porque o tipo de sequestro da mente aí descrito me parece muito mais forte do que o termo "distrair" conota normalmente em Português. Não obstante, "distrair" também poderia ser usado, mas ao preço de uma outra nota que, ao modo desta, viesse acentuar as acepções de distrair como ludibriar, desviar a atenção, direcionar e dirigir a mente, etc. De toda forma, a base etimológica da tradução adotada é, literalmente, $d i s=$ em várias direções + traho $=$ tracionar.

${ }^{16}$ A terminologia da obsessão é minha e não de Espinosa. Todavia, para um conceito equivalente em seu sistema, confira-se a ocorrência de "pertinacia", por exemplo, em Ética IV, proposição 6.
}

Filosofia e Educação - ISSN 1984-9605 - Volume 5, Número 1

Abril - Setembro de 2013 
Aliás, dentre esses três bens ordinários, a honra é descrita como o mais perigoso, pois, ao contrário do prazer, não acarreta fastio $\mathrm{e}$ arrependimento após a fruição, mas incita (incitamur), ao contrário, a um aumento cada vez maior e a uma dedicação cada vez mais intensa (magis ac magis $)^{17}$. Já a riqueza, embora seja grandemente nociva quando desejada por si mesma, possui, todavia, uma versatilidade mais explícita de seu uso e, por isso, não conduz tão automaticamente ao referido fechamento. Tanto é que Espinosa acrescenta, já nesse momento do texto, na nota $a$ do parágrafo 4 , que seria possível

distinguir entre as riquezas que são procuradas (distinguendo divitias quae quaeruntur): ou por si mesmas (vel propter se), ou pela honra (vel propter honorem), ou pelo prazer (vel propter libidinem) ou pela saúde e aumento das ciências e das artes (vel propter valetudinem et augmentum scientiarum et artium $)^{18}$

Se, por um lado, a vida comum, dedicada principalmente à busca desses três bens ordinários, à primeira vista parece marcada por certa

${ }^{17}$ Cf. TIE §5: "mais e mais (magis ac magis) somos incitados a (incitamur ad) (...) aumentar (augendum)". Trata-se de uma incitação a um aumento indefinido, que converte cada fruição em mera etapa subalterna, buscada a bem de outra, a qual, por sua vez, é buscada a bem de outra, etc. É de notar que, como num sistema de juros sobre juros, tratase não de um simples aumento (magis ac magis), mas sim de um aumento do aumentar (ad augendum), um aumento de segunda ordem. Nessa economia de vida, o homem, em progressão geométrica, endivida-se existencialmente na busca de bens fortuitos. Ora, o que de positivo pode, assim, ser aprendido desde já é que uma nova instituição de vida haverá de proporcionar um tipo de economia saudável tão potente quanto esta, mantendo inclusive seu caráter de progressão geométrica. E, de fato, como veremos, o supremo bem assim o faz, sendo um bem de segunda ordem.

${ }^{18} T I E \S 4$, nota $a$. Cabe, a propósito, conjecturar se, em última análise, não seria a natureza mesma das riquezas (divitiae) que permite tomá-las como o menos nocivo dos bens ordinários: penso, sobretudo, na riqueza tomada exemplarmente sob a forma do dinheiro, entendido como um equivalente geral de coisas diversas. O dinheiro é, pois, algo que, por si, remete a algo além de si, a saber, tanto àquilo que ele há de comprar, quanto àquilo (o trabalho) de que é a expressão. Assim, estimo que seja por isso que as divitiae, procuradas propter se, indiquem a avaritia $(C f$. $\S 10)$, mas, procuradas a bem de outra coisa, sejam designadas através do termo nummus (moedas, $C f$. $\S \S 11$ e 17). Entenda-se, porém, que não digo que o dinheiro deixe de ser nocivo por ser um equivalente geral e abstrato: o pensamento espinosano sempre impõe severas restrições a noções dessa sorte, tais como as noções ditas universais. O que observo é que o fato, em verdade comum a todos os bens ordinários, de poderem ser desejados por si ou por outro, é mais explícito no caso do dinheiro, embora isso não impeça que também ele, na dinâmica própria à vida comum, possa aprisionar intensamente o ânimo.

Filosofia e Educação - ISSN 1984-9605 - Volume 5, Número 1

Abril - Setembro de 2013 
multiplicidade, por outro lado, sob essa aparência oculta-se uma concentração obsessiva, que diminui a aptidão do corpo e da mente para a multiplicidade simultânea ${ }^{19}$. Compreende-se, assim, que a mencionada distração (distractio) - o arrastamento em muitas direções, que ocorre na busca dos bens ordinários - não passa de obsessiva repetição. Que esse empobrecedor fechamento à alteridade seja experimentado como busca incessante, agitação, flutuação de ânimo, medo e esperança, não quer dizer que, no vértice desse leque de perturbações, não estejam sempre as mesmas coisas (a riqueza, o prazer e a honra) retornando reiteradamente, sendo sempre provisoriamente conquistadas e provisoriamente perdidas. Veja-se, mais uma vez, a honra, no parágrafo 5 , como caso paradigmático dessa inaptidão para a multiplicidade, pois ela proíbe comportamentos qualitativamente diferenciados, independentes ou singulares, exigindo uma padronização da conduta, já que a vida de quem a busca

deve ser dirigida (est dirigenda) necessariamente (necessario) segundo o juízo dos homens (ad captum hominum), a saber (scilicet), fugindo do que os homens vulgarmente fogem (fugiendo quod homines vulgo fugiunt) e procurando o que vulgarmente procuram (et quaerendo quod vulgo quaerunt).

Não pode ser, portanto, esta sorte de concordância de ideias e desejos - extrínseca e estereotipada, quando não, hipócrita - aquela que se pretende como fruição social de uma mesma natureza humana ${ }^{20}$. Espinosa

${ }^{19} C f$. Ética $V$, prop. 39, escólio. Para um bom resumo sobre a noção de aptidão para a multiplicidade simultânea, veja-se a seguinte passagem de $A$ nervura do Real: "os corpos buscam a relação com outros que formam o vasto meio onde existem, relação que os faz regenerar-se, crescer, desenvolver-se para manter o equilíbrio de suas proporções de movimento e repouso, das quais dependem tanto suas vidas como a ampliação de sua aptidão para o múltiplo simultâneo; e as mentes exprimem em estados afetivos e cognitivos essas relações, graças às quais também se regeneram, crescem e se desenvolvem, fortalecendo sua aptidão para a multiplicidade simultânea de seus pensamentos e ações" (CHAUí, 1999, p 91).

${ }^{20}$ De fato, nesse ponto podemos encontrar em Espinosa uma posição convergente com a crítica heideggeriana da sujeição do indivíduo à ditadura do impessoal: "Assim nos divertimos e entretemos como impessoalmente se faz; lemos, vemos e julgamos sobre a literatura e a arte como impessoalmente se vê e julga; também nos retiramos das 'grandes multidões' como impessoalmente se retira; achamos 'revoltante' o que impessoalmente se considera revoltante. $\mathrm{O}$ impessoal, que não é nada determinado mas que todos são, embora

Filosofia e Educação - ISSN 1984-9605 - Volume 5, Número 1

Abril - Setembro de 2013 
está falando, ao contrário, de um empobrecimento comportamental, correlato de uma conduta heterônoma, na qual a busca e a fuga são determinadas de fora, não sendo a expressão das leis internas da natureza própria de cada indivíduo. E essa homogeneização refratária à diversidade não é apanágio da vida de quem busca a honra como um fim em si, pois todos os bens ordinários, cada um à sua maneira, engendram um modo de vida pautado pela repetição, pela variação meramente quantitativa, sem diferentes diferenças. Se a obsessão típica da vida comum nos incita a buscar sempre mais e mais (magis ac magis), não nos enganemos: trata-se apenas de mais e mais do mesmo. Multiplicidade e movimento nada mais são, aqui, do que atribulada monotonia.

Ora, essa conclusão é importante porque mostra qual deverá ser a natureza do fim último a que a filosofia espinosana se encaminha. A limitação fundamental dos bens ordinários, sua finitude enquanto bens, consiste no fato de que, quando desejados por si mesmos, eles suprimem todo outro objeto do desejo. De modo inverso, só poderá ser infinitamente bom algo que, desejado por si mesmo, ao invés de gerar a escravização ou a extinção do desejo, gere sua expansão em uma multiplicidade de interações diferentes e simultâneas, fazendo sistema com a natureza. Um bem infinito não poderia ser tal que acarretasse a disjunção 'ou ele ou tudo mais' (acaso não seria contraditório um infinito que deixasse tudo mais fora de si?), devendo, antes, ser tal que, buscado como um fim em si mesmo, restituísse tudo mais (um legítimo infinito é o que mantém infinitos entes finitos consistentes dentro de si). Por isso, o que quer que seja legitimamente

não como soma, prescreve o modo de ser da quotidianeidade" (HEIDEGGER, 1988, p 179). Essa inusitada convergência do Tratado da Emenda com o já anteriormente mencionado texto de Heidegger fornece uma justificação — interna ao sistema espinosano — para recusa, no presente artigo, do uso padronizado das formas do impessoal na produção acadêmica: escrevemos artigos como impessoalmente se escreve. Em se tratando aqui de uma publicação em dossiê especialmente dedicado a temas pedagógicos, pareceu-me oportuno chamar a atenção para isso, na forma e no conteúdo desta análise da filosofia de Espinosa. Obviamente, Espinosa é um severo crítico do antropomorfismo e mesmo a categoria do sujeito como consciência de si individual privada; não obstante, é também um crítico, avant la lettre, das formas de usurpação da concretude singular pelo universal abstrato.

Filosofia e Educação - ISSN 1984-9605 - Volume 5, Número 1

Abril - Setembro de 2013 
desejado por si há ser tal que, diversamente do que se passava com os bens ordinários, permita, ou melhor, exija uma verdadeira expansão da vida mental (mais e mais de outro, não do mesmo). Para a pergunta: 'como somente (solum) o verdadeiro bem há de afetar o ânimo e como todos os demais hão de ser rejeitados (rejectis)?', obtém-se, portanto, a resposta: deve-se rejeitar o que leva à empobrecedora rejeição de tudo mais; deve afetar o ânimo exclusivamente o que facultar a aptidão para a multiplicidade simultânea. Numa reviravolta que não seria incorreto chamar de dialética, a rejeição e a exclusividade são recolocadas como rejeição da rejeição e exclusividade da inclusão.

Finalmente, isso determina melhor em que consiste a comunicabilidade do verdadeiro bem. Se foi dito, no parágrafo 1, que o "verdadeiro bem" havia de ser sui communicabile, não se pode, agora, estranhar que ele não se mantenha fechado sobre si mesmo, de um lado, enquanto os bens ordinários permanecem fechados sobre si mesmos, de outro. Há, sem dúvida, uma nítida distinção entre eles, mas esta parece ser justamente que, sendo comunicável, o verdadeiro bem não se isola da vida comum da mesma maneira que esta tende a isolar-se dele. A comunicabilidade impede que o bem, desejado per se, produza aquela distractio. Comunicável, portanto, não é apenas o que pode ser partilhado por todos os homens ao mesmo tempo, mas também o que conecta todos os estados de um só e mesmo homem através do tempo, quando este se põe a "passar" da velha para a nova vida, o que permanece não apesar mas através da mudança. Na acepção aqui pretendida, comunicabilidade é o contrário de unilateralidade ou desarticulação. Um bem comunicável é aquele que não se encontra fora, separado e polarizado contra a vida comum, mas que emerge dentro dela, restituindo-a e potencializando o que ela já possui de positivo em si mesma. 


\section{II.3) Os parágrafos 6 a 10}

Julgo, ademais, ser essa noção de comunicabilidade que, no parágrafo 6 , transparece na adoção do critério da utilidade para decidir qual bem deve ser exclusivo e qual deve ser rejeitado: "eu era forçado a inquirir (cogebar inquirere) o que seria mais útil para mim (quid mihi esset utilius)". Bernard Rousset, numa leitura bastante tradicional nesse ponto, afirma que essa escolha pelo mais útil corresponde à compreensão de que, seja qual for o escolhido, "haverá inevitavelmente uma perda, mas essa deve ser uma perda por um ganho, o que nos conduz a fazer um balanço" (ESPINOSA, 1992, p 153). Avaliar a utilidade seria, nessa leitura, realizar um cálculo racional de perdas e ganhos (embora Rousset, no mesmo passo, tenha o cuidado de advertir que não se trata de um cálculo abstrato, uma vez que é levada em conta a diferença entre o que está e o que não está dado de fato). Marilena Chauí (1999, p 570), por sua vez, considera que, nesta passagem, o narrador "muda o foco para abarcar com nitidez o campo de enfrentamento e perceber o que há de fazer para alcançar o alvo e por isso agora indaga 'o que seria mais útil' para a conservação de seu ser". Sem discordar de ambos os comentadores, eu gostaria apenas de observar que o conceito de útil está intrinsecamente ligado à noção de $u s o$. O útil, enquanto tal, é precisamente aquilo que conduz a algo mais, que pode ser usado para x ou para y. Ora, dentre os três bens ordinários, a riqueza apresenta-se — já o vimos ${ }^{21}$ como exemplarmente útil, uma vez que pode ser usada tanto para proporcionar a honra e o prazer quanto a saúde e o desenvolvimento técnico e científico. Todavia, ainda que a riqueza seja capaz de converter-se numa vasta multiplicidade de outras coisas distintas dela própria, pode, no entanto, quando querida por si mesma, gerar um fechamento obsediante. A distractio

\footnotetext{
${ }^{21}$ Veja-se também Ética IV, Apêndice, Capítulo28: "Em verdade (Verum) o dinheiro (pecunia) conferiu (attulit) um compêndio (resumo, atalho: compendium) de todas as coisas (omnium rerum) donde deu-se que (unde factum ut) sua imagem (ejus imago), maximamente (maxime), costuma ocupar (soleat occupare) a mente do vulgo (Mentem vulgi) a ponto de (quia vix) nenhuma espécie de felicidade (ullam Laetitiae speciem) poderem imaginar (imaginari possunt) a não ser acompanhada (nisi concomitente) da ideia das moedas (nummorum ideâ) como causa (tamquam causa)".
}

Filosofia e Educação - ISSN 1984-9605 - Volume 5, Número 1

Abril - Setembro de 2013 
que nesse caso se produz é, por assim dizer, um arrastamento que separa a mente dos vários objetos a que o útil podia ser direcionado: a própria coisa útil, à parte seu uso em vista de outra coisa, passa a ser desejada como um fim em si mesma (por exemplo: o dinheiro servindo à obtenção de mais dinheiro, servindo à obtenção de mais dinheiro, numa série infinita de etapas sempre insuficientes, sempre subalternas). Nesse caso, dá-se também uma inversão entre as posições do útil e de seu usuário: este passa a viver em função daquele e torna-se o elemento passivo na relação, ao passo que, complementarmente, aquilo que não era senão um recurso a ser usado, um meio, um instrumento, torna-se o protagonista ativo, o agente na relação ${ }^{22}$. Tal inversão encontra eco em uma conhecida frase do parágrafo 7 do Tratado da Emenda:

todas aquelas coisas (illa omnia), porém, (autem) que o vulgo segue (quae vulgus sequitur) (...) frequentemente são causa da morte (frequenter sunt causa interitus) daqueles que as possuem (eorum qui ea possident), e sempre causa da morte (et semper causa interitus) daqueles que por elas são possuídos (eorum qui ab iis possidentur).

Assim, diante da pergunta sobre o quanto ou até que ponto os bens ordinários podem ser úteis, cumpre responder: parcialmente. Por isso, Espinosa os qualificará como incertos "por sua natureza" (sua natura), ao passo que o "verdadeiro bem" é incerto apenas quanto a sua descoberta e aquisição. Se Espinosa qualifica o "verdadeiro bem" através da ideia de fixidez (fixum bonum), não se deve ver aí qualquer sorte de paz inerte ou paralização do ânimo. Por "bem fixo" deve-se entender, antes, algo que não mude de bom para mau em hipótese alguma. Seu — por assim dizer 'valor de bondade' é que possui fixidez: tal bem é fixamente bom, ou seja, de modo incondicional. Os bens ordinários podem ser ou não ser bons,

${ }^{22}$ São desejáveis, aqui, associações - que certamente mereceriam ser trabalhadas a fundo em um outro estudo - entre essa usurpação da atividade e da finalidade pelo útil, descrita pelo espinosismo, e a reversão entre os lugares do sujeito e do objeto, nos processos chamados pela tradição marxista de fetichismo da mercadoria (coisas usurpam o lugar de sujeitos) e de reificação da consciência (sujeitos se degeneram em coisas).

Filosofia e Educação - ISSN 1984-9605 - Volume 5, Número 1

Abril - Setembro de 2013 
dependendo de serem ou não desejados por si mesmos. E o parágrafo 7 extrai, então, as consequências desta combinação: um bem incerto sua natura, efetivamente presente, ao ser desejado per se, equivale a um mal certo! Isso desequilibra os pratos da balança em que as concorrentes formas de viver eram ponderadas, pois já não se trata mais de trocar bens certos (os bens ordinários, certos porque disponíveis em ato) por um bem incerto (no sentido de ainda não haver sido descoberto e adquirido), nem tampouco de trocar um bem incerto por outro igualmente incerto. Em verdade, trata-se de abrir mão de males certos por um bem que permanece apenas circunstancialmente incerto. A situação, para o narrador, é comparável à de um doente (veluti aeger) que, atacado por uma enfermidade letal (letali morbo laborans) e antevendo morte certa (mortem certam praevidet) caso não administre um remédio apropriado (ni adhibeatur remedium), passa a procurá-lo, ainda que incerto (quamvis incertum).

É mediante essa metáfora médica (recorrente ao longo de toda obra de Espinosa) que nosso filósofo, no parágrafo 8, faz uma apresentação de "casos típicos", situações exemplares nas quais os homens perderam ou abreviaram a vida em virtude da busca de bens ordinários como fins em si mesmos. Estes últimos não são, portanto, incondicionalmente úteis à "conservação de nosso ser" (ad nostrum esse conservandum). Bem ao contrário, suas limitações acabam por também limitar a vida de quem os ama; razão pela qual, no parágrafo 9, Espinosa afirma que:

esses males (haec mala) pareciam ser originados (Videbantur esse orta) do seguinte (ex eo), que toda felicidade ou infelicidade (quod tota felicitas aut infelicitas) está situada (sita est) só nisto (in hoc solo), evidentemente (videlicet) na qualidade do objeto (in qualitate obiecti), ao qual aderimos por amor (cui adhaeremus amore).

A qualidade (qualitas) dos bens ordinários — sua finitude determina também a qualidade das comoções do ânimo (commotiones animi) de quem os ama: eles originam litígios (lites) e tristeza (tristitia) caso se extingam (si pereat), inveja (invidia) caso sejam possuídos por outro (si

Filosofia e Educação - ISSN 1984-9605 - Volume 5, Número 1

Abril - Setembro de 2013 
ab alio possideatur) e, de modo geral, temor (timor) e ódio (odium). Em oposição a isso, infere-se, racionalmente, que o objeto do amor deve ser uma coisa eterna e infinita (amor erga rem aeternam et infinitam), que alimenta o ânimo só com alegria (pascit animum sola laetitia). A inferência é clara:

- experimentamos, vimos casos típicos e também ouvimos relatos de que, nas situações particulares de lida com os bens ordinários, existe uma vinculação entre sua finitude e o atribulado fechamento patológico de nosso modo ordinário de vida ${ }^{23}$;

- ora, se - tentando formar uma regra a partir de casos particulares, como é próprio ao conhecimento empírico consideramos que amar algo implica em ficar ligado a isso a ponto de nos co-movermos em função de seus movimentos,

- então, conclui-se — por inferência racional — que para proporcionar uma felicidade suprema, contínua e eterna, o objeto do amor, ao qual o amante está unido, também deve possuir essas mesmas características.

Mas isso ainda é conhecer abstratamente esse objeto, como um algo ou uma coisa (aliquid, res) que vem apenas dar suporte aos predicados que o precedem. Ainda mais: esses predicados foram descobertos por mera oposição a tudo que está dado; o "verdadeiro bem" ainda é um não-bemordinário, ao invés de uma presença afirmativa. É por isso que o narrador relata, ao final do parágrafo 10 , num dos momentos mais dramáticos da narrativa, que:

Embora (quamvis) percebesse (perciperem) tais [coisas] (haec) com

\footnotetext{
${ }^{23}$ Cf. TIE §1: "a experiência ensinou (experientia docuit) que tudo que frequentemente ocorre (omnia, quae frequenter occurrunt) na vida comum (in communi vita) é fútil e vão (vana et futilia esse)". Os "casos exemplares" do $\S 8$, acima mencionados, também podem ser remetidos ao conhecimento por "ouvir dizer".
}

Filosofia e Educação - ISSN 1984-9605 - Volume 5, Número 1

Abril - Setembro de 2013 
muita clareza (adeo clare) pela mente (mente), eu não podia, porém (non poteram tamen), por conta disso (ideo) depor (deponere) toda avareza, prazer e glória (omnem avaritiam, libidinem, atque gloriam)

Ora, se mais acima foi dito que, dependendo de como se concebesse o "verdadeiro bem", ele poderia ou não ser adquirido, isso, para além de qualquer truísmo, manifesta agora todas suas as consequências. Com efeito, a chamada "doutrina dos modos de percepção" 24 ensina que o gênero de conhecimento racional, que infere a essência de algo através de suas propriedades, embora certo, ainda não é plenamente capaz de vencer as paixões nascidas da experiência. Nesse sentido, são particularmente elucidativas as formulações de outra obra de Espinosa que, como o Tratado da Emenda, pertence aos seus primeiros escritos, o Breve Tratado ${ }^{25}$. Resumirei, pois, as formulações que me parecem mais relevantes para a compreensão do ponto ora levantado.

No Breve Tratado, mais precisamente na Parte II, Cap.4, parágrafos 13, Espinosa afirma que, embora à razão caiba o conhecimento correto do bem e do mal, ela se limita, porém, a relacionar-se com o objeto numa irredutível exterioridade. De modo ainda mais detalhado, o parágrafo 2 do Capítulo 22, da mesma Parte, afirma que: "Como tudo o que encontramos em nós mesmos tem mais poder sobre nós do que o que vem de fora, seguese sem dificuldade que a razão pode ser causa da destruição das opiniões que adquirimos por simples testemunho"; mas, por isso mesmo, acrescenta Espinosa em uma nota a esta frase,

não podemos vencer, mediante a razão, aquelas [opiniões/paixões] que estão em nós em virtude da experiência. Com efeito, essas opiniões não são em nós outra coisa senão um gozo e uma união imediata com algo que julgamos bom, enquanto a razão, ainda que

${ }^{24} C f$. TeIXEIRA, L. (2001) e REZENDE, C.N. (2004). Os modos de percepção são: 1) conhecimento por ouvir dizer; 2) conhecimento por experiência vaga; 3 ) conhecimento por inferência racional; 4) conhecimento por ciência intuitiva.

${ }^{25}$ Korte Verhandeling em Holandês, doravante abreviado $K V$. A tradução adotada aqui é a de Atilano Domínguez (ESPINOSA, 1990). As referências suficientes para a localização dos excertos, independentemente da edição usada, seguirão as marcações internas do texto da $K V$, indicando a Parte, o Capítulo e o parágrafo.

Filosofia e Educação - ISSN 1984-9605 - Volume 5, Número 1

Abril - Setembro de 2013 
nos mostre algo que é melhor, não nos faz dele gozar. Assim, aquilo de que gozamos interiormente, não pode ser vencido por aquilo de que não gozamos e que está fora de nós, como é o que nos mostra a razão. Assim, se essas opiniões devem ser superadas, deve existir algo que seja mais poderoso, como será um gozo ou uma união imediata com algo que seja melhor conhecido e gozado do que o anterior - caso em que a vitória é sempre necessária — ou maior que o bem desfrutado ${ }^{26}$.

A tese geral, comum ao Tratado da Emenda, ao Breve Tratado e também à Ética, é a de que não basta a um conhecimento ser verdadeiro e claro (qualidades do conhecimento racional) para que tenha eficácia sobre os afetos. "Video meliora proboque, deteriora sequor"27 é o verso de Ovídio que Espinosa mais de uma vez emprega, a fim de resumir essa tese, ligada ao tema aristotélico da acrasia ou fraqueza da vontade ${ }^{28}$. Observando com atenção, pode-se ver que, no supracitado parágrafo 10 do Tratado da Emenda, essa tese se faz presente, especialmente através do uso do advérbio ideo (i.e. com isso, por isso, com base nisso, etc.), pois ele tem a função de enfatizar que, se por ventura houver alguma possibilidade de que o amor se liberte dos bens ordinários, não será simplesmente de uma percepção clara

\footnotetext{
${ }^{26}$ Não será demasiado indicar também o que diz Espinosa imediatamente antes deste trecho citado ( $K V$ II, 2, §1): "Dado que a razão não tem poder para conduzir-nos à felicidade, não nos resta senão investigar se podemos alcançá-la mediante a quarta e última forma de conhecimento", acrescentando, mais uma vez em nota, que "Todas as paixões que lutam contra a boa razão (...) surgem da opinião. Tudo o que nesta é bom ou mal, nos é mostrado mediante a [razão]. Mas nenhuma destas duas é capaz de nos libertar delas". A "quarta e última forma de conhecimento" será justamente a chamada scientia intuitiva, nos termos da Ética. O Tratado da Emenda, não por acaso, iniciará, depois de encerrado o proêmio, um exame dos modos de percepção, tendo como critério de avaliação o fim que foi caracterizado pelos parágrafos iniciais.

27 "Vejo as coisas melhores e as aprovo, sigo as piores" (Ovídio, Metamorfoses, Livro VII, linha 20).

28 Em tempo: não defendo que haja lugar para a acrasia no sistema espinosano. Contrariando a teoria socrática da ação humana, o acrático é o tipo moral aristotélico que não age mal por ignorância ou erro; ele possui um conhecimento irretocável do ponto de vista epistêmico mas, ao mesmo tempo, uma falha ou interferência na dinâmica volitiva que o conduziria à ação. É nisso que consiste a acrasia ou fraqueza da vontade. Ora, a recusa espinosana da separação entre intelecto e vontade impede, de saída, a ocorrência de estrita acrasia. E à luz dos já citados excertos de $K V$, é possível compreender que o conhecimento que permite o fenômeno, de aparência acrática, em TIE $\S 10$, não é irretocável, visto ser marcado por certa deficiência que Espinosa assinala através da ideia de exterioridade. Por fim, é explicitamente admitida a existência de um conhecimento ainda superior (o que basta para atestar que nem tudo, do ponto de vista cognitivo, havia entrado em cena quando da falha prática).
}

Filosofia e Educação - ISSN 1984-9605 - Volume 5, Número 1

Abril - Setembro de 2013 
que essa conquista advirá de fato: "nem por isso (ideo) eu podia depor, etc".

Na Ética, muitas são as passagens concernentes ao tema dos limites práticos do conhecimento racional do bem e do mal. Não pretendo adentrar nos meandros da obra magna, mas penso que cabe mencionar, pelo menos, o enunciado da proposição 14 da Parte IV. Completando o que dizia o Breve Tratado, tal proposição ajuda a compreender o que se passará na solução que o parágrafo 11 do Tratado da Reforma confere à aporia do parágrafo 10. Diz a proposição 14 de Ética $I V$ :

O conhecimento verdadeiro (Vera cognitio) do bem e do mal (boni et mali) enquanto verdadeiro (quatenus vera) não pode coagir afeto algum (nullum affectum coercere potest) mas apenas (sed tantum) enquanto considerado (quatenus consideratur) como afeto (ut affectus)

\section{II.4) Os parágrafos 11 a 13}

Até a altura do parágrafo 10, a única experiência que ocorreu (envolvendo, pois, fruição e união com o objeto) foi, infelizmente, a da vaidade e futilidade do modo de vida presidido pela união com os bens ordinários: a experiência da falta de um legítimo fim por si, a submissão do ânimo com a atribulada monotonia dessa insuficiência estrutural. De resto, o que se fez, do ponto de vista das operações cognitivas, foi uma pouco segura indução empírica - que passou dessa experiência particular para uma regra geral sobre o funcionamento do amor - e uma inferência racional sobre um objeto que portasse propriedades opostas às desses bens disponíveis. Se deve ser possível vencer a aporia, de aparência acrática, apresentada no parágrafo 10, é preciso que entre em cena não apenas o êxito representacional do conhecimento (quatenus vera) mas também seu aspecto afetivo (quatenus consideratur ut affectus). O modo como o parágrafo 11 faz isso envolve, num mesmo lance, a passagem para uma apreensão mais concreta do "verdadeiro bem", o início da saída do ânimo do jugo dos bens ordinários e, nas palavras de Rousset (1992, p 159) "nada menos que a 
revelação da imanência, que consiste na auto-suficiência da reflexão e vai se definir progressivamente como autonomia do intelecto". De minha parte, quero acrescentar que vejo nesse parágrafo a matriz para determinar o espírito ou caráter da doutrina da educação das crianças, que permanece como objetivo final de toda a presente análise. Portanto, cumpre traduzi-lo integral e meticulosamente:

Eu via (videbam) somente isso (Hoc unum), que enquanto a mente (quod, quamdiu mens) versava acerca de tais pensamentos (versabatur circa has cogitationes) [sc. sobre a coisa eterna e infinita de que falava o §10], durante esse tempo (tamdiu) ela se afastava (aversabatur) daqueles (illa) [sc. avareza, prazer e glória], e seriamente pensava (et serio cogitabat) sobre a nova instituição de vida (de novo instituto), o que foi para mim (quod mihi fuit) de grande alento (magno solatio). Pois via (Nam videbam) aqueles males (illa mala) não serem de tal condição (non esse talis conditionis) que não aceitam ceder a remédios (ut nollent cedere remediis). E embora no início (Et quamvis in initio) esses intervalos fossem raros (haec intervalla essent rara) e durassem (et durarent) por um espaço muito exíguo de tempo (per admodum exiguum temporis spatium) depois, porém (postquam tamen), que o verdadeiro bem (verum bonum) mais e mais (magis ac magis) se me deu a conhecer (mihi innotuit), estes intervalos (intervalla ista) foram mais longos e frequentes (frequentiora et longiora fuerunt); sobretudo (praesertim) depois que eu vi (postquam vidi) que a aquisição (acquisitionem) de dinheiro ou de prazer e glória (nummorum aut libidinem et gloriam) obsta durante o tempo (obesse tamdiu) [em que; lit.: quando] são buscadas (quamdiu quaeruntur) por si mesmas (propter se), e não como meios para outras coisas (et non tamquam media ad alia). Na verdade, porém, (vero), se são buscadas como meios (Si tamquam media quaeruntur), então possuirão moderação (modum tunc habebunt), e não obstarão (et minime oberunt), mas, ao contrário (sed contra), conduzirão sobremaneira (multum conducent) ao fim em vista do qual são buscadas (ad finem, propter quem quaeruntur), como mostraremos no devido lugar (ut suo loco ostendemus).

A fim de explicar como se configura essa nova situação afetiva - de cores mais alegres, como indica o termo "alento" (solatio), que é mais auspicioso do que a mera consolação resignada ${ }^{29}$-, é conveniente começar

${ }^{29}$ Preferi o termo "alento" a "consolação", primeiramente porque o Latim dispõe da palavra consolatio, e depois para evitar as cores afetivas, por exemplo, do 'prêmio de consolação', da resignação diante da impotência, pois não é disso que se trata.

Filosofia e Educação - ISSN 1984-9605 - Volume 5, Número 1

Abril - Setembro de 2013 
atentando ao uso dos advérbios quandiu (durante o tempo, enquanto, desde que, na medida em que, etc.) e tamdiu (por tanto tempo, nesse ínterim, desde então, nessa medida, etc.), que são de procedência temporal embora também possuam uso mais puramente condicional. Através deles, são descritos dois processos que ocorrem no tempo e que possuem uma relação de proporção direta entre suas efetuações: desde que, enquanto e na medida em que acontecia efetivamente $p$ (i.e. a mente versava (versabatur) sobre a coisa eterna e infinita), também acontecia $q$ (i.e. a mente se afastava (aversabatur) de sua dinâmica ordinária), e quanto mais $p$, tanto mais $q$, tendendo a uma passagem da intermitência à continuidade. Ora, a considerar apenas essa forma de funcionamento, seria lícito suspeitar que estamos diante de uma nova distractio, produzida por um novo e mais poderoso objeto obsediante: uma alteração, portanto, apenas no tema da obsessão, na direção (versabatur/aversabatur) do arrastamento, mas não no tipo de instituição da vida que se instaurava. Este seria o caso, por exemplo, do asceta, que, em nome de um supremo bem transcendente, extra mundano, oposto à finitude, nega esta última, isola-se da vida social e recusa o mundo. Mas não é isso que está sendo descrito aqui: a mente não deixava de pensar em tudo mais; pelo contrário, quanto mais a mente perfazia o ato de pensar naquela coisa eterna e infinita, tanto mais ela vivia uma abertura à alteridade e, mais uma vez, quanto mais ela se abria à alteridade, mais pensava naquele infinito, num círculo virtuoso que progride geometricamente. A continuidade a que se tende não é, pois, a estéril homogeneidade que subjaz à distractio, mas sim a que se exigia no parágrafo 1: "suprema e contínua alegria" (summa ac continua laetitia). O magis ac magis do parágrafo 11 é, portanto, estruturalmente distinto do magis ac magis exemplarmente associado à honra. O que este parágrafo narra é, pois, a experiência vivida dessa diferença estrutural, que se exprime na moderação ${ }^{30}$ com que os bens

${ }^{30}$ Literalmente, a expressão do parágrafo 11 é: "se são buscadas como meios ( $S i$ tamquam media quaeruntur), então possuirão modo (modum tunc habebunt)". Ora, etimologicamente, modus liga-se justamente às ideias de medida, ajuste, regulagem e maneira. Mediante o advérbio modo, liga-se à ideia de condição e às expressões 'nem mais

Filosofia e Educação - ISSN 1984-9605 - Volume 5, Número 1

Abril - Setembro de 2013 
ordinários passam a ser desejados quando submetidos à potência de um supremo desejo ${ }^{31}$, supremo precisamente porque, moderador, não precisa ser ele próprio moderado, sendo sempre incondicionalmente bom.

É por isso que Espinosa destaca, usando o advérbio praesertim (sobretudo), que o acontecimento crucial foi ter visto (postquam vidi) que tomar o infinito como incondicionado não leva aos mesmos resultados nefastos de tomar o finito como incondicionado. Já não se trata mais de uma ideia abstrata e negativa acerca do que deveria, por oposição aos bens ordinários, ser o "verdadeiro bem", mas sim de uma experiência concreta da comunicabilidade do verdadeiro bem. É essa experiência concreta que altera o quadro afetivo.

E se Rousset fala aqui de "auto-suficiência da reflexão", tal expressão me parece aceitável se considerarmos que ela não pretende contradizer a tese espinosana de que o conhecimento verdadeiro, enquanto verdadeiro (quatenus vera), não pode coagir afeto algum. O que Rousset parece entrever é, antes, o que eu chamaria de aspecto performativo da situação. Ou seja, - para tomar um exemplo profundamente estudado por Espinosa —, trata-se de um processo cuja estrutura é semelhante à do cogito cartesiano, acerca do qual Descartes perguntava: "Eu sou, eu existo (ego sum, ego existo), isso é certo (certum est), mas por quanto tempo (sed quandiu)?”, para então responder: "Ora, durante o tempo (quandiu) em que penso (cogito)" 32 , pois a cessação do ato de pensar seria, ipso facto, o desaparecimento da existência a que o ato se refere (qual seja, a sua própria). No cogito cartesiano, a reflexão (o pensamento referindo-se a si mesmo e a correlata vivência mental de que é impossível pensar que não estamos pensando enquanto pensamos) só é autônoma quando efetuada,

nem menos', 'na medida em que', 'na proporção em que', 'desde que', 'somente se'. E pelo verbo Modulor, ari, remete a medir, regularizar, estabelecer um ritmo (num contexto musical), movimentar regularmente, etc.

${ }^{31} \mathrm{Cf}$. Ética IV, apêndice, Cap. 4 (summa hominis felicitas (...) finis ultimus, hoc est, summa cupiditas)

${ }^{32}$ Descartes, Meditações. 2a . Meditação §7. AT VII, p 48, 9-11. Negritos meus.

Filosofia e Educação - ISSN 1984-9605 - Volume 5, Número 1

Abril - Setembro de 2013 
quando performada; em contrapartida, quando performada, ela basta para instituir a existência do objeto em que pensa - pois este é o próprio ato de pensamento - e, com isso, torna-se um pensamento necessariamente verdadeiro no sentido de, ao corresponder a si mesmo, corresponder a um objeto real e atual. Assim também, a ideia do verdadeiro bem não possui impacto afetivo algum enquanto meramente representativa (i.e. enquanto detentora de uma extrínseca relação de correspondência com seu objeto), mas apenas enquanto é um ato mental efetivamente performado na duração (modus cogitandi, essentia formalis, no jargão escolástico-cartesioespinosano), pois, à semelhança do cogito, a vivência de haver efetivamente performado a ideia do verdadeiro bem, ao longo do percurso narrado pelos dez parágrafos iniciais, institui a presença de uma vida que já merece ser tida por verdadeiramente boa. Usando palavras que retomam o linguajar do início do Tratado da Emenda, pode-se agora reafirmar que o bom andamento da descoberta (inventio) - isto é, o fato de que "mais e mais (magis ac magis) o verdadeiro bem se me deu a conhecer (mihi innotuit)" implica a progressiva aquisição (acquisitio) desse mesmo bem.

Mais ainda: plenamente descoberto, o verdadeiro bem há de revelarse, de certa maneira, desde sempre na posse de quem, de início, julgava ter de procurá-lo alhures. Sim, pois, sob a ideia adequada do bem infinito e eterno, os bens ordinários - restituídos em sua utilidade, desejados como meios ao invés de serem suprimidos — tornam-se sobremaneira conducentes ao fim (multum conducent ad finem). Ao que vem somar-se num argumento que já foi tido por desconcertante — a passagem do parágrafo 13, segundo a qual "tudo aquilo (omne illud) que pode ser meio (quod potest esse medium) a que se chegue aí (ut eo perveniat) [sc. ao fím visado], chama-se (vocatur) verdadeiro bem (verum bonum)". Ora, os bens ordinários estão “dejá la", presentes em ato, disponíveis, sendo precisamente esta a sua certeza inicial; e agora, mediante a experiência do pensamento do infinito e eterno, eles se revelaram conducentes ao fim; logo,

Filosofia e Educação - ISSN 1984-9605 - Volume 5, Número 1

Abril - Setembro de 2013 
são verdadeiros bens; logo, há verdadeiros bens já na posse de quem, de início, julgava ter de renunciar a esses conteúdos da vida comum. O narrador do proêmio, portanto, fizera muito bem ao considerar inconsulto, lá no parágrafo 2 , simplesmente rejeitar os objetos que povoam a vida comum, pois, caso os houvesse rejeitado absolutamente, ter-se-ia privado do único recurso existente em ato para chegar ao fim último almejado, e uma tal rejeição o teria lançado no ascetismo. Rejeitar os bens ordinários absolutamente seria, pois, tão contrário à conservação de nosso ser quanto desejá-los absolutamente.

Finalmente, para explicitar o que já foi tido por desconcertante nesse passo - e com isso encerrar a análise dos antecedentes dos parágrafos 14 e 15 - é necessário atentar a uma mudança de registro de discurso operada por Espinosa nestes parágrafos 12 e 13, agora em tela. No parágrafo 12, o autor, saindo do registro estritamente narrativo que fora usado até então, passa a propor definições do verdadeiro bem e do supremo bem: "Aqui, apenas direi brevemente (Hic tantum breviter dicam) o que eu entend[o] (quid intelligam) por verdadeiro bem (per verum bonum ) e em simultâneo o que seja o sumo bem (et simul quid sit summum bonum)". Muitos comentadores notaram essa mudança de registro ${ }^{33}$; mas o que pôde ser considerado desconcertante é que, então, torna-se possível perguntar: por que apenas nesta altura é que são definidos conceitos tão importantes e que vieram sendo empregados intensamente no percurso até aqui? O que dizer de seu uso até o momento? Aliás, nesse mesmo sentido seria possível

33 Zweerman (1987, p 80) afirma que se trata da passagem para "uma exposição ontológica do fundamento sobre o qual devem apoiar-se todas as afirmações sobre o homem e sobre a realização de sua vida", com o que estou de acordo. Djin (1996, p 30), por exemplo, sustenta que, desde o início do proêmio, o uso do narrador em primeira pessoa consiste num recurso através do qual o leitor - um homem "qualquer" (the Everyman), conhecedor do pensamento cartesiano, mas que está imerso na dinâmica da vida ordinária que o espinosismo visa superar — pode ingressar na posição de sujeito das ações narradas, identificando-se nas situações descritas e sentindo-se implicado no contexto dramático, de modo a tornar-se mais suscetível às afirmações feitas. Mas, na altura do $§ 12$, Djin, seguindo Zweerman, diagnostica a presença de um outro uso desse pronome pessoal, que corresponderia ao ponto de vista daquele que já fez o percurso apresentado: "the I of the master".

Filosofia e Educação - ISSN 1984-9605 - Volume 5, Número 1

Abril - Setembro de 2013 
protestar que, de fato, houve demasiadas mudanças no valor dos bens ordinários ao longo dessa breve narrativa: de bens certos para bens incertos, de bens incertos para males certos e destes, surpreendentemente, para verdadeiros bens! Isso parece sugerir uma instabilidade semântica no uso do termo verum bonum antes da passagem do discurso a um registro definicional.

Veja-se, como exemplo de tal desconcerto, a leitura desse trecho proposta por H.H. Joachim (1958, pp 20-21), segundo a qual a passagem dos parágrafos 12 e 13 seria "a tal ponto compacta e abrupta que, tomada como está posta, é dificilmente inteligível. (...) A exposição é breve, dogmática e muito inadequada, além de, em um aspecto, verbalmente inconsistente com o que precede". Tal inconsistência verbal adviria do fato de que, por um lado, do parágrafo 1 ao 11, "verum bonum" designava o objeto da inquirição (o que fazia esperar que Espinosa procedesse desenvolvendo sua concepção da "coisa eterna e infinita" que os parágrafos 9 e 10 nos exortam a amar); mas, por outro lado, sem que Espinosa houvesse advertido que o termo "verum bonum" seria provisório, passa, no parágrafo 13, a chamar o fim de summum bonum, e de verum bonum os meios que a ele conduzem (meios, aliás, que acabaram por incluir os males que faziam a miséria da vida comum!). E, de fato, dito assim, tudo isso parece muito inconsistente.

No entanto, em primeiro lugar, quanto ao uso pré-definicional de conceitos chave, é preciso responder que, sem pecar contra a ordem das razões, as próprias definições também possuem uma gênese, sendo, pois, não somente pontos de partida mas também pontos de chegada, embora de processos distintos. São pontos de partida para as demonstrações, mas pontos de chegada para um trabalho preliminar chamado historia (de acordo com um vocabulário de matriz baconiana) ${ }^{34}$. A respeito dessa historia, é

\footnotetext{
${ }^{34}$ Confira-se, a propósito, a Carta 37, de Espinosa a Bowmeester. Nela, nosso filósofo escreve que, para entender a distinção entre imaginação e intelecto puro, bem como as leis de funcionamento deste último, pelo menos o quanto o método exige, não é mister conhecer a mente por sua causa primeira, mas é o suficiente compor (sufficit concinare)
}

Filosofia e Educação - ISSN 1984-9605 - Volume 5, Número 1

Abril - Setembro de 2013 
oportuno conferir, muito rapidamente, o que ensina o Capítulo VII do Tratado Teológico-Político, onde o esquema geral de produção de definições é apresentado a partir do que há em comum entre a produção das definições das coisas naturais e das coisas de que falam as Sagradas Escrituras. O método de interpretar a natureza consiste em "organizar uma história da natureza, a partir da qual (ex qua), assim como a partir de dados certos (utpote ex certis datis), concluímos (concludimus) as definições das coisas naturais (rerum naturalium definitiones)". Do mesmo modo, o método de interpretar as Escrituras consiste em compor sua história sincera (sinceram historiam adornare) e, a partir do que nela se colige, concluir as definições desde as quais as deduções serão feitas. Esse procedimento é empregado porque, assim como a natureza, as Escrituras também não trazem (Scriptura non tradit) as definições (definitiones) das coisas de que falam (rerum de quibus loquitur). No caso da natureza, deve-se partir do levantamento de suas diversas ações (ex diversis naturae actionibus); no caso das Escrituras, deve-se partir das diversas narrações (ex diversis narrationibus) sobre uma mesma coisa ou assunto (de unaquaque re). E no caso do proêmio do Tratado da Emenda: principia-se por uma experiência vivida, passa-se a coligir as coisas que os homens comumente estimam como supremo bem, faz-se uma redução destas a três principais; passa-se a um levantamento dos frequentes exemplos de resultados letais nascidos de tal estima e, a partir do que se depreende dessa historia de vida — análoga à história das ações da natureza ou das narrações das Escrituras — chega-se às definições de "verdadeiro bem" e "supremo bem". Portanto, o uso prédefinicional que veio sendo feito dos conceitos de "verdadeiro bem" e "supremo bem" não é espúrio, visto que encontrava-se controlado pelas regras desse procedimento chamado historia, que Espinosa apresenta e justifica nessas outras obras aqui citadas.

uma pequena história das percepções (historiolam perceptionum), daquele modo que Verulâmio (Bacon) ensina. Sobre o uso do conceito baconiano de história nesta Carta, no Tratado Teológico-Político, no Tratado da Emenda e em outros textos de Espinosa, confira-se REZENDE (1997 e 2004b).

Filosofia e Educação - ISSN 1984-9605 - Volume 5, Número 1

Abril - Setembro de 2013 
Mas, em segundo lugar — e independentemente dessas referências externas ao Tratado da Emenda —, é preciso perceber que este último também possui em si mesmo as justificativas de sua démarche. Com efeito, no parágrafo 12, Espinosa enuncia formalmente quais sejam as condições para que essas definições sejam corretamente inteligidas (ut recte intelligatur):

deve-se notar (notandum est) que "bom" e "mau" (quod bonum et malum) não [são] ditos senão relativamente (non nisi respective dicantur), a tal ponto que uma só e mesma coisa (adeo ut una, eademque res) pode ser dita boa e má (possit dici bona et mala) segundo diversas relações (secundum diversos respectus) e do mesmo modo "perfeito" e "imperfeito" (eodem modo ac perfectum, et imperfectum). Pois nada (Nihil enim) considerado em sua natureza (in sua natura spectatum) será dito perfeito ou imperfeito (perfectum dicetur vel imperfectum); sobretudo (praesertim) depois que tivermos sabido (postquam noverimus) que tudo que se faz (omnia, quae fiunt) se faz (fieri) segundo uma ordem eterna (secundum aeternum ordinem) e segundo leis certas da natureza (et secundum certas naturae leges)

Ora, no próprio parágrafo de abertura do Tratado da Emenda (§1), o autor iniciara o proêmio atribuindo às vivências, que começava a narrar, o aprendizado de que os objetos e as causas de seus temores nada possuíam de bom ou mal em si mesmos (nihil neque boni neque mali in se habere), a não ser enquanto o ânimo fosse por eles movido (nisi quatenus ab iis animus movebatur). Essa relatividade do bem e do mal, do perfeito e do imperfeito, foi precisamente o que se experimentou ao longo de todo o proêmio, correspondendo ao conteúdo da história de vida que antecedeu a elaboração de definições. É por isso que apenas agora - lastreados não só na experiência da vaidade e futilidade dos bens ordinários mas principalmente na experiência alentadora do parágrafo 11 - os conceitos protagonistas do proêmio podem aceder a um nível definicional.

Não obstante, o que há de inegavelmente novo no parágrafo 12 é a tese do determinismo tático-nomológico — tudo que se faz está determinado quanto à ordem e às leis de sua gênese - , bem como a

Filosofia e Educação - ISSN 1984-9605 - Volume 5, Número 1

Abril - Setembro de 2013 
afirmação de que o conhecimento desse determinismo confere fundamento e caráter necessário à experiência vivida da relatividade do bem e do mal: o narrador aprendeu com a experiência que os bens ordinários não são nem bons nem maus por sua natureza, eles são — justamente por isso - incertos em sua natureza e só se tornam certamente maus se forem tomados como supremos bens. O que o narrador não sabe é por que isso acontece, e tal resposta efetivamente só poderá ser dada na Mea Philosophia, a filosofia plenamente desenvolvida (a Ética), para a qual Espinosa destina várias discussões do Tratado da Emenda. Mas uma pessoa que, por ventura, já houvesse partido de uma perspectiva filosófica suficientemente conhecedora dessa resposta, isto é, do universal determinismo tático-nomológico, jamais duvidaria da relatividade do bem e do mal, do perfeito e do imperfeito ${ }^{35}$. Afinal, como, por hipótese, essa pessoa já aceita que tudo está sujeito às leis e à ordem da natureza, então, de saída, necessariamente já admite que nada deveria ter ocorrido de modo diferente do que efetivamente ocorreu, nada sendo, portanto, ao mesmo tempo, real, de uma parte, e imperfeito ou perfeito, mau ou bom, de outra. O narrador não partiu dessa perspectiva filosófica, ele chegou a ela através da experiência, sendo o proêmio a narrativa em flashback dessa chegada. Portanto, o narrador não precisa da tese do determinismo para chegar às definições de verdadeiro e soberano bem, visto que elas podem ser elaboradas com base na história da gênese concreta da experiência que culmina no já mencionado alento.

E que o narrador não estivesse, de saída, de posse da compreensão de que tudo se faz conforme a lei e a ordem da natureza, é algo que o parágrafo 13 vem imediatamente justificar: a fraqueza humana (humana imbecillitas) não permite seguir essa ordem pelo pensamento, muito embora perceba não ser impossível adquirir uma natureza humana muito mais firme (multo firmiorem) do que essa. Surge, assim, um novo incitamento, diverso do incitamento obsessivo de busca dos bens ordinários: o homem "é incitado

\footnotetext{
${ }^{35}$ Há uma analogia aqui com o que diz Espinosa acerca de seu método, defendendo-o de uma possível acusação de circularidade nos $\S \S 43$ e 44 do TIE.
}

Filosofia e Educação - ISSN 1984-9605 - Volume 5, Número 1

Abril - Setembro de 2013 
(incitatur) a buscar meios que conduzam (ad quaerendum media quae ducant) ele próprio (ipsum) a tal perfeição (ad talem perfectionem)". E é então que são apresentadas as já mencionadas definições de verdadeiro e supremo bem, cujos enunciados cumpre agora citar integralmente:

Tudo aquilo (omne illud) que pode ser meio (quod potest esse medium) para que se chegue aí (ut eo perveniat) [sc. à tal perfeição] chama-se verdadeiro bem (vocatur verum bonum). Supremo bem, no entanto, (Summum autem bonum) é chegar aí (est eo pervenire), de modo que ele [i.e. o homem] frua (ut ille fruatur) de tal natureza (tali natura) com outros indivíduos (cum aliis individuis), se possível (si fieri potest). Qual seja, porém, aquela natureza (Quaenam autem illa sit natura) mostraremos em seu devido lugar (ostendemus suo loco) ser, sem dúvida (nimirum esse) o conhecimento da união (cognitionem unionis) que a mente tem (quam mens habet) com a natureza inteira (cum tota natura).

O que é surpreendente - ou talvez mais propriamente engenhoso e agudo, mas não desconcertante - é que, portanto, o supremo bem, a aquisição de uma natureza humana mais perfeita, é justamente aceder a um ponto de vista a partir do qual deixa de fazer sentido falar de "bem" e "mal" e de "perfeito" e "imperfeito", ao menos enquanto estas noções forem referidas às próprias coisas em si mesmas consideradas. Uma vez libertos dessa reificação do bem e do mal, a felicidade contínua - que sempre foi, sem inconsistência verbal alguma, o que a posse do verdadeiro bem havia de proporcionar - passa a ser possível a partir de qualquer coisa. O mundo, a natureza inteira, com todas as coisas singulares que agora podem ser tomadas como verdadeiros bens, é a coisa infinita e eterna à qual devemos nos ligar por amor. A natureza, esta é a coisa (res), o objeto ou conteúdo da felicidade $^{36}$. E só depois de compreendido isso é que os predicados que a

36 Confira-se, no Breve Tratado, o Primeiro Diálogo, que traz como personagens Amor (Liefde), Intelecto (Verstand), Razão (Reede) e Concupiscência (Begeerlykheid). A personagem Amor, abrindo o diálogo, afirma que sua própria perfeição depende das três outras personagens na exata medida em que elas concebem ou compreendem (begrepen) objetos (voorwerp). Amor, então, lhes pede que, enquanto são potências cognitivas, digam se conhecem um ser (wezen) sumamente perfeito (oppersten volmaakt), que não possa ser limitado (bepaald) por nenhum outro. À solicitação de Amor, Intelecto responde - numa breve e única fala - que vê ou contempla (aanschouw), como sendo o objeto solicitado, "a natureza (Natur) como um todo (als geheel)". É de notar a semelhança entre o pedido

Filosofia e Educação - ISSN 1984-9605 - Volume 5, Número 1

Abril - Setembro de 2013 
precederam adquirem pleno sentido, não mais abstrato: o verdadeiro bem é único, comunicável, infinito e eterno da maneira como a natureza é única, comunicável, infinita e eterna.

Já o supremo bem - designado sempre no singular por abarcar a multiplicidade de bens verdadeiros — é o conhecimento que reordena qualquer coisa, na natureza, da maneira mais útil à conservação do nosso ser, que não é outra senão a que aumenta nossa aptidão à multiplicidade simultânea. Ou melhor, o supremo bem é ser ou fruir de uma natureza humana tal que realize esse conhecimento, de modo que, sem que tenhamos de rejeitar nossas paixões — uma tarefa intrinsecamente fadada ao fracasso - possamos fruir, sem interrupção, de suprema felicidade. Jamais deixaremos de conviver com os bens ordinários e com os afetos que eles nos suscitam; o summum bonum nunca virá, nalgum dia, como um novo bem a suplantá-los no mesmo registro que lhes é próprio. Sendo bom no superlativo - e não comparativa e comensuravelmente bom —, ele se encontra, por assim dizer, num 'desnível' que, ao contrário de separá-lo, constitui um outro registro ou categoria que lhe permite, sem contradição, coabitar a vida com os demais. É por isso que se pode dizer que o summum bonum é um bem de segunda ordem. Não há, na verdade, nenhuma 'outra vida' que virá num 'outro tempo' - por exemplo, post mortem — com um novo conteúdo particular, com novos bens povoando-a. O que há é estritamente tudo que já está dado, e a perdição ou a salvação dependem de podermos tomar esse disponível em muitos sentidos ou relações. O supremo bem não é, pois, uma coisa - que seria como um fim em si mesmo no interior da série dos acontecimentos da vida humana - mas, por assim dizer, a forma da felicidade, que acolhe, contém e organiza todos os verdadeiros bens em uma estrutura consistente. E assim, completa-se e de Amor e a inquirição que abre o TIE, de sorte que o animus nesta obra, ou melhor, seus movimentos ou afetos, parecem desempenhar o papel que Amor ocupa no Breve Tratado. A isso também vem somar-se, nos $\S \S 9-10$ do TIE, a mesma doutrina ora evocada por Amor no Breve Tratado: "toda felicidade ou infelicidade (tota felicitas, aut infelicitas) está situada somente nisto (in hoc solo sita est), a saber (videlicet), na qualidade do objeto ao qual aderimos por amor (in qualitate objecti, cui adhaeremus amore)".

Filosofia e Educação - ISSN 1984-9605 - Volume 5, Número 1

Abril - Setembro de 2013 
torna-se inteligível a gradual transformação na qualificação dos acontecimentos da vida comum, em oposição à instituição da nova vida: bens certos / bem incerto; bens incertos por sua natureza / bem incerto quanto à consecução; males certos / bem certo; verdadeiros bens (meios) / supremo bem (fim); verdadeiros bens (conteúdos) / supremo bem (forma).

Foi assim que os bens ordinários, os bens verdadeiros e o supremo bem mais e mais (magis ac magis) foram sendo compreendidos. O que foi de grande alento.

\section{III - As regras da simultaneidade (§§ 16-17)}

\section{III.1) O parágrafo 16}

Recordemos: de início, era impossível, para um mesmo homem, buscar, ao mesmo tempo, os bens ordinários e o verdadeiro bem. Mas, depois dos parágrafos 11-13, o fim da empreitada deixa de ser concebido abstratamente e por negação dos bens ordinários — isto é, como objeto que portasse propriedades opostas às desses bens disponíveis - e passa a ser concebido como princípio de reorganização desses mesmos conteúdos, situando-se, assim, em uma outra ordem lógico-ontológica. O mesmo homem pode buscar os dois tipos de bens ao mesmo tempo porque não os busca no mesmo sentido ou na mesma relação: busca uns como meios e o outro como fim, e eles coexistem como, respectivamente, conteúdo e forma de uma mesma vida. A conversão dos bens ordinários em verdadeiros bens depende, pois, da capacidade do pensamento para trabalhar com esse tipo de relatividade que constitui a terceira cláusula da formulação aristotélica do Princípio de Não Contradição (PNC): “é impossível (adúnaton) pertencer e não pertencer (hupárchein te kaì mé hupárchein) o mesmo (tò autò) (1) ao mesmo (tó autó $_{i}$ ), (2) ao mesmo tempo (háma) e (3) no mesmo sentido (kata tò autò)" (Aristóteles, Metafísica, 1005b 19). Essa capacidade de pensar em muitos sentidos ou muitas relações, ou seja, a capacidade de operar com a terceira cláusula do $\mathrm{PNC}$ - na medida em que possibilita o 
reconhecimento de bens verdadeiros desde sempre em nossa posse, apenas inicialmente mal estruturados —, pode ser dita, portanto, ela própria, algo suma e fixamente bom. Quero, com efeito, dar todo destaque a essa capacidade de superar contradições por meio de tal cláusula, pois considero que seja ela a presidir a ideia, introduzida no parágrafo 16 , de que, antes de tudo mais (ante omnia) — ou seja, antes de cuidarmos da moral, da educação das crianças, da mecânica e da medicina — devemos

excogitar um modo (excogitandus est modus) de medicar e expurgar o próprio intelecto (medendi intellectus ipsumque expurgandi), tanto quanto possível de início (quantum initio licet), para que ele intelija as coisas (ut intelligat res) com felicidade (feliciter), sem erro (absque errore) e de modo ótimo (et quam optime).

Sem que o intelecto esteja de plena posse de seus princípios - isto é, no presente caso, sem todas as cláusulas do PNC —, a moral, a educação das crianças, a medicina e a mecânica poderiam degenerar-se em cúmplices da servidão. E que tais degenerações de fato ocorrem é algo que Espinosa reconhece, por exemplo, no parágrafo 49 do Capítulo VIII do Tratado Político:

As academias (Academiae), que são fundadas (quae fundantur) às expensas da República (sumptibus Reipublicae), são instituídas (instituuntur) não tanto (non tam) para que os engenhos sejam cultivados (ad ingenia colenda ${ }^{37}$ ) quanto para que os mesmos (quàm ad eadem) sejam coartados (coercenda) $)^{38}$

${ }^{37}$ Eu gostaria de dar destaque a este verbo colo, -ere (cultivar, lavrar, cuidar, ocupar, habitar, frequentar, cultuar), de onde se deriva o particípio passado cultum (cultivado) ou o verbo português colonizar (ocupar e tomar posse pelo cultivo) e o adjetivo agrícola (que cultiva o campo). Essa gama de sentidos será importante para a compreensão, logo mais, do que seja o trabalho medicinal com o intelecto, pois tratar-se-á bem mais de um cultivo (semelhante ao que o jardineiro faz de seu jardim) do que uma cura na acepção tecnicista hodierna: eliminar a doença. Aliás, a própria palavra cura comporta esse sentido de cultivo, tal como se verifica, por exemplo, nas ideias de curador e curadoria, onde sobressai mais a contínua atividade de cuidar do que a produção de uma cura como estado final resultante.

${ }^{38}$ A tradução de Diogo Pires Aurélio foi aqui consultada e utilizada em suas principais soluções lexicais (EsPINOSA, 1988). Devo ao artigo de Fernando Bonadia de Oliveira (2011/2012), sobre “A educação no Capítulo 9 do Apêndice da Ética IV de Espinosa", a percepção de que, neste excerto citado, Espinosa de fato escreveu, ainda que brevemente, sobre uma educação totalitária institucionalizada. De modo geral, para uma crítica

Filosofia e Educação - ISSN 1984-9605 - Volume 5, Número 1

Abril - Setembro de 2013 
E o modo como tais degenerações ocorrem é algo que também pode ser vislumbrado, no mesmo Tratado Político, no parágrafo 4 do Capítulo VI, onde Espinosa, defendendo que a Paz não é a mera ausência de guerra, critica a incapacidade de certas formações sociais para comportarem em seus interiores a diversidade e o conflito:

Sem dúvida (sane), mais numerosas e mais acerbas contendas (Plures \& acerbiores contentiones) costumam ser movidas (moveri solent) entre pais e filhos (inter parentes \& liberos) do que entre senhores e escravos (quam inter dominos \& servos). Todavia (tamen), não é do interesse da gestão doméstica (nec Oeconomiae interest) mudar o direito paterno (Jus paternum mutare) em domínio (in dominium) e ter o filhos (\& liberos habere) assim como escravos (perinde ac servos).

É do interesse da servidão e não da paz eliminar sumariamente quaisquer formas de contendas, oposições e contradições. Por isso, as sociedades democráticas são preferíveis às tiranias, não propriamente por serem melhores, mas sim por serem mais naturais, isto é, em maior conformidade com o próprio sistema da natureza, que é um todo infinitamente infinito, superlativamente complexo de infinitas maneiras. Com efeito, para que um todo não se torne tão frágil quanto rígido, é necessário elevar ao máximo as condições de coexistência do múltiplo que o constitui e não a homogeneidade supressiva. E isso não apenas no interior dos todos que são a natureza ou a sociedade, mas também daquele que é o próprio indivíduo, tanto em seu corpo quanto em sua mente. Donde podemos deduzir que a mencionada tarefa de medicar e expurgar o intelecto — essa Medicina da Mente ${ }^{39}$ — não pode ser o estabelecimento de uma

espinosana a um uso degenerado da razão, veja-se também REZENDE (2004). Seria, pois, extremamente profícuo investigar na obra espinosana a degeneração da moral em moralismo, da medicina em biopolítica e da mecânica em tecnocracia, embora tais conceitos obviamente não apareçam sob estas denominações anacrônicas no léxico do filósofo seiscentista. Ou seja, as tarefas elencadas em TIE $§ 15$ compõem um promissor roteiro de estudos para o pesquisador que quiser investigar as formas sociais da servidão que compõem a contraface das formas sociais de emancipação pensadas por Espinosa.

${ }^{39}$ Medicina Mentis é a expressão com que E.W. von Tschirnhaus, correspondente de Espinosa, bem parafraseou a Emendatio Intellectus (Cf. TSCHIRNHAUS, 1980)

Filosofia e Educação - ISSN 1984-9605 - Volume 5, Número 1

Abril - Setembro de 2013 
tranquilidade inerte, de uma paz de espírito obtida como homogeneização da vida psíquica. A união da mente com a natureza inteira nada tem a ver com uma suposta dissolução da mente individual no seio do absoluto (como uma gota no oceano da indiferença, para evocar imagens hegelianas, empregadas na tentativa de reduzir o espinosismo ao eleatismo e ao ascetismo).

Espinosa é, nesse sentido, bom herdeiro de alguns princípios da medicina antiga, pois é perfeitamente possível reconhecer aqui a tese atribuída a Alcméon de Crotona (Cf. JAEGER, 1979, p 963) - de que o estado patológico consiste em uma monarchia (hegemonia de uma parte sobre as demais, usurpação do lugar do todo por uma das partes), sendo a cura o restabelecimento de uma isomoiria (igualdade proporcional das partes) e de uma isonomia (igualdade das leis que presidem as relações entre essas mesmas partes). E é de notar que, também na medicina antiga, nenhum dos elementos é tido como bom ou mau em si mesmo, sendo má apenas a desproporção ou desordem entre eles. Essa purificação não homogeneizante, essa medicação que nada acrescenta mas apenas restabelece - mediante a terceira cláusula do $\mathrm{PNC}$, discernindo o quanto, o como, o quando e diversos outros respeitos - a ordem e a proporção entre o que já está presente, é o que, no parágrafo 18, Espinosa designará com a palavra "emenda", a qual, dado seu caráter menos usual em nossa língua, parece mais propícia para absorver tais aspectos do que os dois termos já empregados para traduzir emendatio em Português: "reforma" e "correção". Trata-se, talvez, de uma cura do intelecto (CHAUÍ, 1999, p 668), mas apenas se o termo "cura" estiver subordinado ao paradigma dessa medicina das proporções, ou seja, uma cura pensada não como a destruição de um estado nosológico positivamente mau mas sim como um cuidado, uma curadoria, um cultivo de si, que tanto conserva quanto promove a saúde. A medicina mentis espinosana é, assim como a medicina antiga, "uma medicina de sãos" $\left(\right.$ JAEGER, 1979) ${ }^{40}$.

40 É utilíssimo termos em conta, para a boa compreensão da Medicina Mentis espinosana, o seguinte conjunto de ideias levantadas por W. Jaeger sobre a medicina

Filosofia e Educação - ISSN 1984-9605 - Volume 5, Número 1

Abril - Setembro de 2013 


\section{2) O parágrafo 17}

Mas, antes de chegarmos definitivamente ao parágrafo 18 e a seu conceito de emendatio, é crucial — principalmente para a determinação do caráter ou espírito da doutrina da educação das crianças - atentar com cuidado ao parágrafo 17. Nele, comprova-se o núcleo daquilo que este artigo se propôs a demonstrar, a saber: que o agrupamento de tarefas de que partimos, no parágrafo 15, corresponde à recuperação, num plano conceitual mais elaborado, dos mesmíssimos objetos de desejo que, num primeiro momento, eram impedimentos para a aquisição da felicidade.

No parágrafo 17, Espinosa enumera três regras de vida (regulas vivendi) que, antes de mais nada (ante omnia), somos obrigados a supor (cogimur supponere) como boas (tanquam bonas), visto que é necessário viver (necesse est vivere) enquanto (dum) dedicamos trabalho (operam damus) a reconduzir o intelecto à reta via (intellectum in rectam viam). Ora,

antiga entendida como paideia: "O verdadeiro médico surge sempre como o homem que nunca separa a parte do todo, mas sempre a encara nas suas relações de interdependência com o conjunto [...] médico é chamado a restaurar a medida oculta, quando a doença a vem alterar. Em estado de saúde, a própria natureza se encarrega de a implantar, ou antes, é ela própria a justa medida. [...] Não é em intervir contra a natureza que consiste a função do médico no tratamento dos doentes. Os sintomas da doença, e sobretudo a febre, representam já de si o início de restabelecimento do estado normal [...] o médico se limita a averiguar onde pode intervir para ajudar o processo natural [...] 'A natureza a si própria ajuda': tal é o supremo axioma da teoria médica hipocrática. [...] $\mathrm{Na}$ concepção hipocrática, a paideia [não é uma disciplina e uma domesticação puramente exterior, pois] já tem o seu caminhar inconsciente na própria natureza [...] [A]ssim como o médico facilita com sua arte a obra da natureza, quando se altera o equilíbrio dela, também é esta mesma concepção que incute a este autor [sc. Alcmeón] o dever de prevenir o perigo que espreita e de velar pela conservação do estado normal. O médico antigo, como o moderno ainda até há poucas décadas, era mais um médico de sãos do que de enfermos. Esta parte da medicina resume-se sob o nome de higiene. Os cuidados da higiene incidem sobre a dieta. Os gregos entendem por dieta não só a regulamentação dos alimentos do enfermo, mas também todo regime de vida do Homem e especialmente a ordenação dos alimentos e dos esforços impostos ao organismo [...] É, pois, explicável que o ginasta, como conselheiro experiente no cuidado do corpo, fosse o precursor do médico [...] É desta raiz que brota o uso genial de analogias materiais para interpretar o espiritual [...]: 'o esforço físico é alimento para os membros e para os músculos, o sono o é para as entranhas; pensar é para o homem o passeio da alma"” (JAEGER, pp 970-977). A emenda do intelecto é bem uma higiene e um exercitar fortalecedor de uma verdade que já nos habita. O método não é para chegar à verdade, mas para perseverarmos nela no mais alto grau. E o fim buscado não é um telos extrínseco, que se deposita como produto residual do exercício, mas sim um "institutum", um regime de vida. Cf. supra, nota 37, sobre colo, -ere.

Filosofia e Educação - ISSN 1984-9605 - Volume 5, Número 1

Abril - Setembro de 2013 
a primeira coisa a observar aí é, certamente, essa necessária simultaneidade (marcada pela conjunção — por vezes usada como advérbio - dum: enquanto, durante o tempo em que, ao mesmo tempo em que, no momento em que; contanto que, etc.). Quer dizer, ainda havia, à altura do final do parágrafo anterior, algo que tinha de ser feito antes da medicação e expurgação que ali eram prescritas: tratava-se não simplesmente do estabelecimento de certas regras de vida, mas sobretudo do reconhecimento de que a obtenção do fim e a própria purificação do intelecto não podem realizar-se num tempo ou numa existência separados do tempo e da existência já dados. Ou seja, quando Espinosa dizia que, antes de cuidarmos da moral, da educação das crianças, da mecânica e da medicina, devemos medicar e expurgar o intelecto, tal antecedência devia ser entendida como anterioridade lógica e não temporal. Medicar e expurgar o intelecto é uma condição para a compreensão e a consecução do fim, mas, para realizar essa terapêutica, é necessário compreender que ela precisará ser simultânea à vida em curso, não sendo possível ao homem uma retirada, de estilo cartesiano, para um hiato de suspensão numa "pacífica solidão": é preciso, ao contrário, consertar o navio enquanto ele já está a navegar. E é notável que, depois dessa advertência, Espinosa não fale mais de expurgar ou medicar, mas precisamente de emendar o intelecto.

Mas o mais importante para uma justa compreensão do caráter da doutrina da educação das crianças é observar, juntamente com tal simultaneidade, que cada uma dessas três regras versa justamente sobre cada um dos três bens ordinários antes tidos por perniciosos:

I - Ao alcance do vulgo (Ad captum vulgi) falar (loqui) e fazer (et operari) tudo aquilo (illa omnia) que nada traga de impedimento (quae nihil impedimenti adferunt) para que $<$ não $>^{41}$ (quominus) atinjamos nosso escopo (nostrum scopum attingamus). Pois, não pouco de emolumento (Nam non parum emolumenti) podemos adquirir disso (possumus acquirere ab eo), desde que (modo)

41 A expressão quominus introduz uma dupla negação não tolerada pelo sentido da frase em Português.

Filosofia e Educação - ISSN 1984-9605 - Volume 5, Número 1

Abril - Setembro de 2013 
façamos concessões (concedamus), tanto quanto se possa fazer (quantum fieri potest), ao seu alcance (ipsius captui); acrescente-se que (adde quod), por tal modo (tali modo), apresentar-se-ão (praebebunt) ouvidos amigos (amicas aures) para ouvir a verdade (ad veritatem audiendam).

II - Fruir dos deleites (Deliciis frui) somente o quanto seja suficiente (in tantum, in quantum sufficit) para manter a saúde (ad tuendam valetudinem).

III - Por fim (Denique), buscar de dinheiro (nummorum quaerere) ou de qualquer outra coisa (aut cuiuscumque alterius rei) somente o quanto baste (tantum quantum sufficit) para que a vida e a saúde sejam sustentadas (ad vitam, et valetudinem sustentandam) e para que sejam imitados (et ad imitandos) os costumes da cidade (mores civitatis) que não se oponham ao nosso escopo (qui nostrum scopum non oppugnant).

Recordemos, pois, que ao final do parágrafo 11 Espinosa dissera que mostraria, no devido lugar (suo loco), como os bens ordinários não prejudicariam e conduziriam sobremaneira ao fim se fossem buscados como meios e possuíssem moderação. Ora, tal lugar não é senão este parágrafo 17. A primeira regra é claramente a moderação da busca pela honra, que, imoderada, obrigava o homem a buscar o que impessoalmente se busca e a fugir do que impessoalmente se foge (a proceder ad captum hominum, como dizia o parágrafo 5, numa clara antecipação da expressão ad captum vulgi agora citada). Como já foi dito, a verdadeira bondade é comunicável porque não se encontra fora, separada e polarizada contra a vida comum, mas emerge dentro dela, redimindo-a e potencializando o que ela já possui de positivo. Destarte, compreendemos com maior precisão que a dimensão social e política do fim encontra-se atrelada justamente à recuperação do amor que, desde o início, já existia em ato pela honra (honra que, aliás, era o mais perigoso dos bens ordinários!). Já a segunda regra, concernente aos deleites e delícias, é uma patente moderação do prazer. E a terceira regra, versando sobre o dinheiro - ou o que quer que se queira comprar com ele - é uma evidente moderação da busca e do uso das riquezas.

E observando com mais atenção, é possível ir ainda mais longe e notar que os próprios afazeres enumerados no parágrafo 15 figuram, sem exceção, 
em alguma dessas três regras:

- a Medicina, pela saúde que proporciona, liga-se à regra II supracitada, concernente à moderação do prazer;

- a Mecânica, que constitui uma área explicitamente aprovada pelo programa espinosano para o investimento do dinheiro, liga-se, pois, à moderação das riquezas, controladas pela regra III (regra que também faz a intendência do uso do dinheiro com a saúde e com os mores sociais). Ademais, subordinando ciência e técnica a um processo mais amplo, de orientação ética, tal uso controlado do investimento em Mecânica permite que sejam resgatadas e dignificadas as comodidades que o narrador hesitava em abandonar no início do proêmio. Aquilo que poderia tornar-se um lucro supérfluo de tempo e de facilidades a desviar e consumir o ânimo, reverte-se agora num auxílio necessário, integrado ao encadeamento de todos os misteres humanos sob a direção do fim.

- Finalmente, a Filosofia Moral e a Doutrina da Educação das crianças (formas concretas do esforço para interferir no intelecto e no desejo dos homens, estipuladas pelo aspecto social indissociável do fim almejado) figuram, sob a regra I, concernente à moderação da honra, como uma generosa e engenhosa atenção para com o vulgo, do qual podem ser esperadas orelhas amigas da verdade, se a elas dirigirmo-nos com respectividade $^{42}$ (ou seja, com respeito para com suas especificidades).

A época de reconduzir o intelecto à reta via e de perseguir o supremo bem não é, portanto, anterior, posterior ou de qualquer modo oposta à presença do conteúdo da vida comum, mas simultânea e articulada com ele, o qual figura, então, como um infinito acervo de meios disponíveis em ato. Também as tarefas apresentadas no parágrafo 15 não são, pois, expedientes preliminares ou preparatórios, mas devem perdurar como partes (sub-rotinas constitutivas) da vida coletiva almejada: enquanto esta transcorre e para que possa perseverar transcorrendo, é preciso dedicar trabalho quotidiano à moral, à educação das crianças, à medicina e à mecânica. Ou, por outras palavras, não se deve confundir as regras do parágrafo 17 com uma "moral provisória" de estilo cartesiano.

${ }^{42}$ Cf. Cogitata Metaphysica I, 4: "Considerada só a coisa (Res sola considerata), ela não pode ser dita nem boa nem má (neque bona dicitur, neque mala), mas apenas respectivamente a outra (sed tantùm respectivè ad aliam) [...] e assim uma mesma coisa (ideòque unaquaeque res) pode ser dita boa e má ao mesmo tempo (eodemque tempore bona, \& mala potest dici) com relação diversa (diverso respectu)".

Filosofia e Educação - ISSN 1984-9605 - Volume 5, Número 1

Abril - Setembro de 2013 
É verdade que as palavras com que Espinosa introduz tais regras despertam inevitáveis associações com a moral provisória cartesiana. E não deixa de ser correto afirmar, por exemplo, com Carlos Lopes Matos, que tanto para Descartes quanto para Espinosa "a necessidade da vida não pode esperar o acabamento do sistema filosófico" (Mimeo, s/d). Mas não se pode ir tão longe ao ponto de pensar, como Matos, que, para Espinosa, "a admissão dessas regras, que poderiam no final, em tese, ser condenadas, baseia-se na distinção entre a prática e a especulação" (id. ibd. Itálicos meus $)^{43}$, o que supostamente encontraria amparo na seguinte passagem da Carta 56 de Espinosa:

É verdade (verum est) que fazemos muito (Nos multa facere) no mundo (in mundo) a partir de conjectura (ex conjectura), mas é falso (sed est falsum) que tenhamos (nos habere) nossas meditações (nostras Meditationes) a partir de conjecturas (ex conjecturâ). Na vida comum (in comuni vita), somos obrigados a seguir (cogimur sequi) o mais verossímil (verisimillimum), mas na especulação (in Speculationibus verò), a verdade (veritatem). O Homem pereceria de fome e de sede (Homo siti \& fame periret) se não quisesse comer ou beber (si edere aut bibere nollet) antes de obter a demonstração perfeita (antequam perfectam obtinuisset demonstrationem) de que a comida e a bebida (cibum ac potum) lhe seriam proveitosos (sibi profuturum). Mas isso não tem lugar (Id autem locum non habet) na contemplação (in Contemplatione). Pelo contrário (Econtra), devemos nos precaver (cavendum nobis est) de admitir como verdadeiro (admittere tanquam verum) o que quer que seja somente verossímil (quicquam quod solummodò verisimile est): pois (enim) onde admitimos uma falsidade (ubi unam admisimus falsitatem),

${ }^{43}$ Em seus apontamentos (não publicados) para preparação das notas de sua tradução do TIE, Matos não encontra apenas semelhanças entre a moral provisória cartesiana e as regras espinosanas supostas como boas. Ele, ao contrário, registra ao menos três diferenças: (i) as regras cartesianas vêm para evitar a inação a que a dúvida pode levar, ao passo que Espinosa não supõe essa dúvida; (ii) Descartes obtém suas regras morais a partir das regras metódicas, enquanto Espinosa as apresentaria como decorrentes de uma "necessidade óbvia"; (iii) as regras de Descartes procuram aproximar-se de uma moral perfeita, mas as de Espinosa são "mais utilitárias, visando as condições materiais para uma frutuosa meditação”. Todavia, mesmo tais diferenças não me parecem corretas, especialmente no ponto (ii), onde há um completo descaso com a verdadeira origem textual dessas regras, qual seja: a permanência do conteúdo da vida comum na instauração da nova vida (permanência sem a qual a nova vida seria tão impossível quanto ininteligível). E desse descaso decorre a desvalorização de fundo que se exprime nas afirmações citadas aqui no corpo do texto: as regras espinosanas seriam desejáveis de fato mas condenáveis de direito, o que, pelo que já foi demonstrado, é incorreto.

Filosofia e Educação - ISSN 1984-9605 - Volume 5, Número 1

Abril - Setembro de 2013 
infinitas se seguem (infinitae sequuntur).

Entretanto, Espinosa aí fala da vida comum, ao passo que, conforme procurei demonstrar, o parágrafo 17 fala do conteúdo que pertencia à vida comum mas que passou a coexistir com o esforço por uma outra vida, dedicada justamente à produção e à fruição coletiva do conhecimento. Como bem observa RousseT (1992, p 175-176), responder, no Tratado da Emenda, à questão sobre o que fazer com os bens próprios à vida comum, "não é viver provisoriamente: é administrar definitivamente a vida". Ademais, como ficou evidente desde o destaque dado à importância da performance do ato de pensar no parágrafo 10, o que se descreve no proêmio não pode ser confundido com um expediente meramente contemplativo, pois o puro êxito representacional não levaria o homem a "seguir o melhor" (para evocar o dito ovidiano). Não se trata, pois, de contemplar a vida, trata-se de transformá-la, mudando a ordem e conexão de seus conteúdos ${ }^{44}$. E, por fim, o próprio apelo à Carta 56 está mal ajustado ao contexto do Tratado da Emenda, pois a passagem citada da Carta versa, antes, sobre o uso impróprio que, na missiva precedente, o interlocutor de Espinosa, Boxel, pretendera fazer do princípio aristotélico segundo o qual não é preciso procurar a mesma certeza em todos os assuntos (Boxel quer defender seu direito de conjecturar sobre espectros (spectra) e duendes (lemures), sua geração e seus sexos). No entanto, ao invés de pretender abrir o campo do conhecimento a conjecturas que não se comprometem nem sequer com o rigor da verossimilhança, o que Aristóteles pretendia era, antes, defender que não se deve procurar certeza matemática no campo prático, como se deve buscar no campo teorético (Aristóteles, Ética a Nicômaco, 1094b11-1095a 2). E mesmo quanto a este último ponto, o

\footnotetext{
44 Também é útil notar que, em TIE §58, o usus vitae é evocado como algo que revela a impossibilidade da epoché do cético: a vida impede a separação entre a ideia e o julgamento. Mas, afinal, para Espinosa, essa separação não é impossível pela própria natureza da ideia? Não é esta uma das razões palas quais Espinosa recusa o método dubitativo? Um estado de indiferença é tão impossível na vida quanto na própria contemplação. A suppositio de TIE $\S 17$ se afigura mais internamente necessária do que suspeitou Carlos Lopes Matos.
}

Filosofia e Educação - ISSN 1984-9605 - Volume 5, Número 1

Abril - Setembro de 2013 
paradigma espinosano é totalmente outro, como se pode ver, por exemplo, pela própria pretensão de demonstrar a ética ao modo dos geômetras, ou de demonstrar, na política, "por razões certas e indubitáveis (certâ, \& indubitatâ ratione) aquilo que concorda (quae conveniunt) com a prática (cum praxi)", como diz o Tratado Político (Capítulo I, §2). Podemos, assim, pensar que, no diálogo com Boxel, Espinosa pressiona seu interlocutor impondo-lhe a correta leitura de Aristóteles ou a bem conhecida posição de Descartes sobre a suspensão meditativa das crenças pragmáticas da vida, mas não exatamente a sua própria concepção sobre a relação entre teoria e prática. A suposição (suppositio) das regras como boas no parágrafo 17 do Tratado da Emenda não está, portanto, no mesmo contexto das conjecturas (coniecturae) da carta 56.

Aliás, dentre os textos de Espinosa, seria bem mais adequado aproximar as regras do parágrafo 17 ao escólio da proposição 10 de Ética $V$. $\mathrm{O}$ enunciado de tal proposição - inclusive na temporalidade que descreve - corresponde precisamente ao parágrafo 11 do Tratado da Emenda:

por quanto tempo (quamdiu) não estamos sob o conflito (non conflictamur) de afetos que são contrários à nossa natureza (affectibus qui nostrae naturae sunt contrarii), por tanto tempo (tandiu) temos poder (potestatem habemus) de ordenar e concatenar (ordinandi et concatenandi) as afecções do corpo (corporis affectiones) segundo uma ordem para o intelecto (secundum ordinem ad intellectum)".

E seu escólio vem, então, dizer o mesmo que o parágrafo 17:

com efeito (igitur), o melhor que podemos fazer (Optimum quod efficere possumus), durante o tempo (quandiu) em que não possuímos um conhecimento perfeito (perfectam cognitionem non habemus) dos nossos afetos (nostrorum affectuum), é conceber uma regra [lit: razão] reta de viver (est rectam vivendi rationem concipere) ou seja, certos dogmas de vida (seu certa vitae dogmata) [...] Mas é de notar (Sed notandum) que, em ordenando (quod in ordinandis) nossos pensamentos e imagens (nostris cogitationibus et imaginibus), sempre hemos de atentar (semper nobis attendendum est) [...] àquilo que, em cada coisa (ad illa quae in unaquaque re) é bom (bona sunt), para que (ut) sempre sejamos assim determinados (sic semper determinemur) a agir (ad agendum) a partir de um afeto

Filosofia e Educação - ISSN 1984-9605 - Volume 5, Número 1

Abril - Setembro de 2013 
de alegria (ex Laetitiae affectu).

Não se trata aqui de uma moral provisória, mas de uma consequência da própria perspectiva radicalmente imanentista da filosofia de Espinosa. E é exatamente essa passagem à perspectiva da imanência que, a partir do parágrafo 18 , presidirá a investigação mais marcadamente epistemológica que então se inicia. A emenda do intelecto aí proposta será a compreensão - a partir de uma história das percepções - daquilo que, numa ordem dedutiva, Espinosa demonstrará na proposição 33 de Ética II, isto é, que "Nada há de positivo nas ideias (Nihil in ideis positivum est) pelo que possam ser ditas falsas (propter quod falsae dicuntur)”. Assim como no âmbito ético haveremos de atentar àquilo que em cada coisa é "bom", assim também, na epistemologia, Espinosa atentará àquilo que em cada modo de percepção é positivamente real.

\section{IV - Emendatio e acompanhamento do erro (§18)}

A assimilação das linhas de trabalho do parágrafo 15 (Mecânica, Medicina, Moral e Pedagogia) às três regras do parágrafo 17, e destas à reincorporação dos três bens ordinários (riquezas, libido e honra), evidencia a integração de cada passo da narrativa ao todo do proêmio. Torna-se possível, destarte, compreender qual seja a unidade subjacente ao conjunto de afazeres que incluem a Doutrina da Educação das crianças. Como vimos, Espinosa afirmara, na nota $d$ do parágrafo 14 , que não estava preocupado em ordenar mas apenas em enumerar as ciências necessárias ao seu escopo. Ora, se as regras do parágrafo 17 são justamente um reaproveitamento daqueles mesmos bens ordinários que faziam a miséria da vida comum, então, a partir da presente perspectiva, fica patente que todos os afazeres derivados no parágrafo 15 também consistiam numa das faces desse processo de transformação da honra, do prazer e da riqueza em "bens verdadeiros" (sendo a doutrina da educação das crianças uma transformação do amor pela honra).

Filosofia e Educação - ISSN 1984-9605 - Volume 5, Número 1

Abril - Setembro de 2013 
Uma vez isto posto, Espinosa, no parágrafo 18, não falará mais de expurgar e medicar, mas sim de emendar o intelecto:

Isto assim posto (Hisce sic positis), cingir-me-ei ao primeiro (me accingam ad primum), que deve ser feito antes de tudo (quod ante omnia faciendum est), a saber (scilicet), a emendar o intelecto ( $a d$ emendandum intellectum), tornando-o apto (eumque aptum reddendum) a que as coisas sejam inteligidas (ad res intelligendas) do tal modo que é mister (tali modo, quo opus est) a que atinjamos nosso fim (ut nostrum finem assequamur). Para que isso seja feito (Quod ut fiat), a ordem que naturalmente temos exige (exigit ordo, quem naturaliter habemus) que eu resuma aqui (ut hic resumam) todos os modos de perceber (omnes modos percipiendi) que possuí até agora (quos hucusque habui) para negar ou afirmar algo (ad aliquid affirmandum vel negandum) independentemente de dúvidas (indubie), para que eleja o melhor de todos (quo omnium optimum eligam) e simultaneamente (et simul) [para que] comece a conhecer (noscere incipiam) as minhas forças e natureza (meas vires et naturam) que desejo aperfeiçoar [Lit. perfazer] (quam perficere cupio).

É interessante notar, a propósito da expressão "emendar o intelecto, tornando-o apto (aptum reddendum)", que a significação clássica do verbo reddo, ere (composto de red + dare = dar de volta) é "restituir" (em geral, algo a alguém); e com dois acusativos, como é o caso (reddere $A=$ intellectum $B=$ aptum), significa (i) reconduzir algo em um estado $A$ a um estado anterior $B$, ou simplesmente (ii) fazer algo, em um estado $A$, passar a um outro estado $B$. No texto supracitado, os tradutores parecem preferir a opção (ii) — que aqui foi mantida — mas julgo que não se deva perder de vista o sentido (i), pois a emenda do intelecto, para além da mera correção ou reforma deste último, é o restabelecimento de sua potência natural para o conhecimento verdadeiro. Seria tentador traduzir a frase em questão da seguinte maneira: “... emendar o intelecto restituindo sua aptidão para inteligir...”. E que o intelecto passe a inteligir não é, obviamente, uma aquisição de novos predicados, mas apenas o pleno exercício de sua natureza. $\mathrm{Na}$ mesma direção, seria tentador traduzir a última frase do parágrafo não como "conhecer as minhas forças e natureza que desejo aperfeiçoar (quam perficere cupio)”, mas sim “... que desejo perfazer”.

Filosofia e Educação - ISSN 1984-9605 - Volume 5, Número 1

Abril - Setembro de 2013 
Espinosa não pretende que o homem deixe de ser humano: aperfeiçoar-se é simplesmente perfazer-se, é tornar-se plenamente o que se é, e não aceder a um patamar sobre-humano. Como ensinará o prefácio da Ética IV, passar de uma menor perfeição a uma maior, ou o inverso, não é mudar de uma essência ou forma em outra, mas é aumentar ou diminuir a potência de agir, enquanto entendida através da própria natureza da coisa. A natureza humana mais firme é humana e firmemente humana, e se é dita mais perfeita, é simplesmente porque não se perde na malfadada busca de ideais de perfeição que lhe são exteriores, ou seja, porque não se aliena.

Assim como a saúde não é a eliminação da doença, a paz não é a supressão da guerra, o bem supremo não é a rejeição dos bens ordinários e a felicidade não é a extinção das paixões, assim também a emendatio não será uma eliminação do erro e a certeza não será a mera ausência de dúvidas. A partir do parágrafo 18 , um dos principais aprendizados a conquistar será, isto sim, a compreensão de que a verdade é algo de positivo na própria ideia, ela própria um ente real, uma ação da mente... Adentrar adequadamente neste novo terreno exigiria, porém, uma análise minuciosa da segunda parte do Tratado da Emenda ( $\S 19-29)$, o que obviamente excede o recorte proposto neste artigo. Mas o que podemos antecipar desde já é que o conceito espinosano de emenda operará justamente segundo essa estratégia imanentista de sempre recuperar algo através do que isso possui, em ato, de positivo em si mesmo.

Aliás, parece ser em razão dessa estratégia que Espinosa emprega, no supracitado texto do parágrafo 18, o adverbio indubie para caracterizar a forma como todos os modos de percepção negam ou afirmam: eles não estão sendo postos em dúvida mas tão somente considerados naquilo que têm em comum ${ }^{45}$. E também parece ser por isso que são todos chamados de percepções, inclusive aquele que - mais tarde revelando-se essencialmente

\footnotetext{
${ }^{45}$ Há, aqui, uma pequena polêmica acerca da tradução e da interpretação advérbio indubie em TIE §18. Tal polêmica pode ser verificada, por exemplo, na nota 18 de C. L. Matos (Cf. ESPINOSA 1979, p 48).
}

Filosofia e Educação - ISSN 1984-9605 - Volume 5, Número 1

Abril - Setembro de 2013 
ativo - muito mereceria ser designado com outro nome, pois, como explica a definição 3 de Ética II, o nome de percepção (perceptionis nomen) parece indicar (indicare videtur) que a Mente sofre a ação do objeto (Mentem ab objecto pati). No Tratado da Emenda, em todos os modos de perceber será reconhecida uma eficácia própria. De uns, o autor declarará que espontaneamente "nunca duvidou" (nunquam dubitavi); outros serão ditos inabaláveis (inconcussum) em certas circunstâncias; ainda outros serão ditos aptos a tirar conclusões que podem ser ditas certas, e todos, de uma maneira ou de outra - pois é nisto que consistem: em maneiras de perceber - conseguirão resolver problemas semelhantes, e até um mesmo problema (como a descoberta do quarto número proporcional, numa série de três números dados), chegando, todos, ao resultado correto (TIE §§19-24). Assim, indubie não deve ser traduzido por indubitavelmente, mas sim por "independentemente de dúvidas", pois o que Espinosa agora procura é antes o sentido dessas percepções e não imediatamente sua verdade. Afinal, como é bem sabido desde o Sofista de Platão, o falso, para que possa ser falso, há de ser inteligível (e ele o é, em Espinosa, como parcialidade ou privação).

Do parágrafo 18 em diante, isto é, a partir do momento em que o que é prescrito é designado como emenda, o que de fato se põe em prática não é imediatamente um expediente de eliminação da falsidade, mas sim uma espécie de fenomenologia do erro, ou seja, uma história das percepções em sentido baconiano - que descreve detalhadamente como se erra, como se dá o erro, como é possível errar. Serão examinadas as ideias fictícias (fictae), falsas (falsae) e duvidosas (dibiae). E o método principiará justamente por distingui-las (distinguere) e separá-las (separare) da idea vera (TIE §50), mas não ao modo de uma segregação desarticuladora e sim do mesmo modo como o supremo bem foi discernido e separado da vida comum, ou seja, com o estabelecimento de um desnível categorial que permitirá que a ideia verdadeira se faça presente entre as demais, 
iluminando-as em suas positividades próprias ao manifestar-se a si mesma ${ }^{46}$. Se deve haver, evidentemente, alguma forma de "rejeição" do erro, isto é, de inteligir sem erro (TIE §16: intelligere absque errore), é sobretudo através desse conhecimento de como o erro existe que sua superação poderá se dar.

Valendo-me de certo jargão pedagógico, de matriz construtivista, creio ser plenamente lícito falarmos aqui de um "acompanhamento do erro", acompanhamento que deve anteceder e controlar qualquer expediente corretivo, porquanto, assim não sendo, o aprendiz ficaria subordinado a um cânone abstrato do aprendizado, e este último, por sua vez, degenerar-se-ia em mero adestramento comportamental ${ }^{47}$. Uma doutrina espinosana de educação das crianças seria, destarte, condizente com a elaboração de um método de conhecimento que não assumisse imediatamente uma "voz imperativa", enunciadora de um dever ser. Seria uma doutrina que não precisaria extirpar os modos "primitivos" do conhecimento, não científicos

46 Cf. TIE §37: “[o método é] inteligir o que seja a ideia verdadeira (est intelligere, quid sit vera idea) distinguindo-a das demais percepções (eam a ceteris perceptionibus distinguendo) e investigando sua natureza (eiusque naturam investigando), para que, a partir disso (ut inde) conheçamos nossa potência de inteligir (nostram intelligendi potentiam noscamus) e coibamos nossa mente de tal modo que (et mentem ita cohibeamus ut) segundo essa norma (ad illam normam) intelija tudo o que é a inteligir (omnia intelligat, quae sunt intelligenda)". Este coibir está para o âmbito epistêmico como a rejectio do $\$ 1$ está para o plano ético. Ou seja: não se deve ver aqui qualquer expediente supressivo ou desarticulador.

${ }^{47}$ Kant não é normalmente elogioso para com Espinosa. Todavia, removidos todos os traços de ascetismo que a tradição insistiu em atribuir ao filósofo holandês, seu conceito de emendatio quadraria muito bem com a seguinte passagem do Curso de Lógica Geral de Kant: "A fim de evitar erros [...] é preciso procurar descobrir e explicar a fonte dos mesmos: a aparência. Pouquíssimos, porém, foram os filósofos que fizeram isso. Eles só trataram de refutar os erros mesmos, sem apontar a aparência em que tinham origem. Esta descoberta e dissolução da aparência é um serviço à verdade de muito mais mérito do que uma refutação direta dos erros mesmos, com o que não se consegue obstruir a fonte desses erros, nem evitar que a mesma aparência, pelo fato de não ser conhecida, venha de novo a induzir em erros em outros casos. [...] De resto, com a explicação da aparência dá-se uma espécie de aprovação a quem errou. Pois ninguém há de admitir que errou sem qualquer aparência de verdade" (KANT, 1992, p 73). Kant e Espinosa são, pois, dos poucos que teriam atentado a essa fenomenologia do erro. Talvez restasse apenas insistir que essa "eliminação" da aparência, em Espinosa, não é a destruição das representações imaginativas: o fato de sabermos que a visão mostra o distante como pequeno não faz que deixemos de ver o Sol no céu com o tamanho de uma moeda. Todavia, reconduzindo tal aparência às suas causa, já não erraremos mais, pois não estaremos, então, privados da ideia que impedia a asserção de que o Sol é menor do que a Terra.

Filosofia e Educação - ISSN 1984-9605 - Volume 5, Número 1

Abril - Setembro de 2013 
ou intelectuais. Proscritos sem serem descritos, esses conhecimentos "imperfeitos" subtrairiam consigo a compreensão de como, afinal, alguém pode vir a aprender alguma coisa. A falência seria a mesma da inconsulta eliminação precoce dos bens ordinários no contexto ético. E no campo epistêmico, cumpriria lembrar, por exemplo, da célebre comparação espinosana entre a construção do conhecimento pelos instrumentos intelectuais e o forjamento do ferro pelos instrumentos corporais (TIE $\S \S$ 30-31), onde o processo construtivo do saber evolui progressivamente de uma força nativa para instrumentos primitivos e destes para novas forças e para novos instrumentos cada vez mais potentes e potencializadores. Portanto, na face pedagógica da ética e da epistemologia de Espinosa, uma das atitudes mais adequadas diante da ocorrência de um erro seria considerar este último inserido no mesmo processo contínuo que também poderá comportar o acerto. $\mathrm{O}$ erro, naquilo que possui enquanto um evento real (enquanto ato mental performado), tem suas razões de ser, e estas devem ser consideradas para que o conhecimento "sem erro" não seja o resultado da aplicação de um método negativo, absolutamente extrínseco e desarticulado do conteúdo por ele agenciado. Para que o acerto não seja um efeito externo da educação - o produto residual de um comportamento estereotipado - é preciso, pois, no modo do indicativo e não do imperativo, “acompanhar os erros". Esse acompanhamento não consiste em deixar-se levar pelo erro, mas sim em examinar seu acontecimento e corrigi-lo somente através da compreensão das leis que presidem sua ocorrência efetiva (pois tudo, inclusive o erro, se faz segundo as leis e a ordem da natureza: o erro representa mal a natureza, mas ele próprio é parte dessa natureza que ele falha em representar, exprimindo-a, pois, inexoravelmente). O erro é, assim, corrigido internamente, a partir do que ele próprio possui de real, positivo e perfeito em si mesmo. Nos termos de Espinosa: o erro é emendado.

Filosofia e Educação - ISSN 1984-9605 - Volume 5, Número 1

Abril - Setembro de 2013 


\section{Conclusão: a criança à luz da Emenda do Intelecto}

Com o final do proêmio no parágrafo 18 , a emenda do intelecto começa a iluminar a variedade dos conhecimentos humanos, desde as suas formas mais elementares até o modo de percepção superlativamente bom (optimus). Mas isso não significa conceder privilégio a tal ou qual percepção considerada como primeira ou última: trata-se, pelo contrário, de tomar consciência de uma construção indefinida do conhecimento e, sobretudo, de tomar consciência de que, para compreender suas razões e seus mecanismos, é preciso conhecer todos os seus gêneros. Este conhecimento dos conhecimentos - um conhecimento de segunda ordem, equivalente ao summum bonum como o bem dos bens - é o que a doutrina espinosana do método caracterizará como reflexão ou ideia da ideia (TIE §38), que engendrará um método perfeitíssimo quando a reflexão tiver por base a ideia do ente infinito, eterno e perfeitíssimo (qual seja: a Natureza/Substância/Deus). Mas o espírito ou caráter desse método é tal que ele jamais pode deixar de resgatar, emendativamente, as formas cognitivas mais "imperfeitas", como são as formas infantis, eminentemente imaginativas.

A partir de um brevíssimo recenseamento das referências de Espinosa à infância na Ética, isso pode ser suficientemente comprovado.

Com efeito, no escólio da proposição 2 de Ética III, Espinosa assemelha a criança ao delirante (sic delirans [...] puer) na medida em que ambos crêem falar por um livre decreto da vontade - quando, na verdade, só estão a exprimir certa constituição (constitutio) de suas mentes e de seus corpos - o que não creriam se não estivessem privados de algo que os impedisse de fazê-lo (como, por exemplo, no caso da criança, de muitas experiências). Pois, afirma Espinosa, se os homens não houvessem experimentado (nisi experti essent) que fazemos muitas coisas das quais depois nos arrependemos, e que nós, quando somos tomados por afetos contrários, frequentemente vemos o melhor e seguimos o pior, nada os 
impediria de crer (nihil impediret quominus crederent) que nós fazemos tudo livremente (nos omnia liberè agere). É assim que "um bebê (infans) crê apetecer livremente o leite, e uma criança (puer) irada, a vingança, enquanto a tímida, a fuga". A criança ilustra, pois, paradigmaticamente, a situação em que alguém é cônscio de suas ações mas ignorante das causas pelas quais é determinado a agir, ou seja, a situação em que, embora haja certa percepção, o contexto mental em que ela se insere carece de outras que a ponham em questão.

A criança também é usada como protagonista de um exemplo fornecido no escólio da proposição 44 de Ética II, que afirma ser da natureza da razão contemplar as coisas não como contingentes mas como necessárias. A criança (puer) figura, então, como aquele que percebe o mundo contingentemente e, portanto, ainda não o contempla segundo a perspectiva da razão. O exemplo é construído de forma a descrever uma situação mental muito simples (e por isso a criança é escolhida, porque possui um pequeno repertório de percepções, as quais estabelecem entre si relações associativas muito elementares). A criança do exemplo vê, pela primeira vez, Pedro de manhã, Paulo ao meio-dia, e Simão à tarde. E assim como alguém que, pela primeira vez, constata que a água apagou o fogo e mantém essa afirmação pensando 'água apaga fogo', assim também a criança seguirá pensando que 'Pedro vem com a manhã, Paulo com o meiodia e Simão com a tarde'. Mas, caso perceba, alguma vez, certa ocorrência discrepante - por exemplo, em vez de Simão, Jacó vem com a tarde — na manhã seguinte imaginará, ao mesmo tempo que a tarde, ora Simão, ora Jacó, mas não os dois juntos. Isto é, imaginará que pode vir com a tarde tanto um quanto outro, como futuros contingentes. Ora, o sistema da contingência é precisamente aquele da "distração" e do revolvimento entre o medo e a esperança, descrito no proêmio do Tratado da Emenda, correspondendo a estados mentais que, apesar de sua aparência agitada e atribulada, derivavam justamente de uma profunda exiguidade.

Filosofia e Educação - ISSN 1984-9605 - Volume 5, Número 1

Abril - Setembro de 2013 
Note-se, aliás, que esse escólio sobre os futuros contingentes começa por referir-se à proposição 17 da mesma Parte II e a seu corolário, no qual se diz que, se o corpo foi uma única vez (semel) afetado pelos corpos exteriores, isso bastará para que a mente venha a contemplar tais corpos como se estivessem presentes, mesmo quando não mais estiverem. Essa indevida permanência — por falta de oposição — da percepção do ausente não se deriva senão da exiguidade contextual da mente e do corpo de quem a afirma. Ora, desenvolvida a partir dessa perspectiva, encontramos, ao final do escólio dessa proposição 17 , uma clara referência aos fundamentos da estratégia emendativa espinosana, particularmente relevante no que concerne ao modo de encarar os erros imaginativos típicos das crianças:

E aqui (Atque hic) para que eu comece a indicar (ut indicare incipiam) o que seja o erro (quid sit error) quero que noteis (notetis velim) que as imaginações da mente (mentis imaginationes) em si mesmas consideradas (in se spectatas) nada de erro contêm (nihil erroris continere); ou seja, (sive) a mente não erra (mentem non errare) pelo [fato] de que imagina (ex eo quod imaginatur) mas somente enquanto (sed tantum quatenus) é considerada carecer de uma ideia (consideratur carere idea) que exclua (quae secludat) a existência daquelas coisas (existentiam illarum rerum) que ela imagina (quas imaginatur) presentes a si (sibi praesentes). Pois, se a mente (Nam si mens), enquanto imagina (dum imaginatur) coisas não existentes (res non existentes) como presentes a si (ut sibi praesentes), simultaneamente soubesse (simul sciret) que essas coisas não existem de verdade (res illas revera non existere), [então] certamente atribuiria (sane tribueret) essa potência de imaginar (hanc imaginandi potentiam) a uma virtude e não a um vício (virtuti non vitio) de sua natureza (suae naturae)

E que corresponda a uma situação tipicamente infantil essa permanência da imagem, inconcussa por falta contextual de oposição, é algo que se pode verificar, por exemplo, no escólio da proposição 49 de Ética II, onde Espinosa retorna ao exame da causa do erro para, desta vez, recusar que ela seja - como pensava Descartes - um excesso da vontade, a qual viria, desde fora da ideia, afirmar-lhe abusivamente o conteúdo. Para Espinosa, a vontade e a ideia são, antes, uma só e mesma coisa, donde a causa do erro ser estritamente "uma privação (privatio) que as ideias

Filosofia e Educação - ISSN 1984-9605 - Volume 5, Número 1

Abril - Setembro de 2013 
mutiladas e confusas (mutilatae et confusae) envolvem". E, para defender tal posição, Espinosa apela justamente ao tipo da criança, a fim de mostrar que não há, estritamente falando, qualquer ato voluntário de assentimento ou suspensão do juízo sobre a existência do que se pensa na ideia (como seria supostamente o caso de um ficcionista que finge um cavalo alado, sem crer que esse animal exista na realidade). A isso Espinosa responde dizendo que:

Concebamos uma criança (concipiamus puerum) imaginando um cavalo alado (equum alatum imaginantem) e não percebendo (nec percipientem) qualquer outra [coisa] (aliud quicquam). Uma vez que (Quandoquidem) essa imaginação de cavalo (haec imaginatio equi) envolve existência (existentiam involvit) (...) e a criança não percebe (nec puer percipit) o que quer que tolha a existência desse cavalo (quicquam quod equi existentiam tollat), ela necessariamente contemplará (ille necessario contemplabitur) o cavalo como presente (equum ut praesentem) e não poderá duvidar (nec poterit dubitare) da existência dele (de ejus existentia) embora dela não esteja certo (quamvis de eadem non sit certus).

Tal situação não corresponde à positiva certeza, mas à mera ausência de dúvidas, ilustrada por esse quasi-sonho das vigílias imaginativas da infância. De modo diverso, a suspensão do juízo de um ficcionista adulto é o efeito da presença de um grande acervo mental de múltiplas percepções simultâneas, de diversos tipos, adquiridas e organizadas ao longo da vida, e não o efeito de um ato livre de sua vontade: "quando dizemos que alguém suspende seu juízo, não dizemos senão que ele vê que não percebe ${ }^{48}$ adequadamente a coisa", como ensina o mesmo escólio. As ideias fictícias — ponto de partida e paradigma para o exame dos modos de percepção no Tratado da Emenda - proliferam na proporção inversa da complexidade e da consistência da mente de quem as pensa, de sorte que, no caso limite (TIE §53), "se for dado (si detur) algum Deus (aliquis Deus) ou algo onisciente (aut omniscium quid), absolutamente nada (nihil prorsus) ele

${ }^{48}$ Itálico meu. É de notar aqui a situação reflexiva: trata-se claramente de um conhecimento de conhecimento — ou seja, de um conhecimento de segunda ordem aquele que caracteriza a condição do ficcionista maduro, o qual, enquanto ficcionista, não assente àquilo que ele próprio forja.

Filosofia e Educação - ISSN 1984-9605 - Volume 5, Número 1

Abril - Setembro de 2013 
pode fingir (eum posse fingere)". A possibilidade da ficção, da falsidade e da dúvida redunda sempre com a ignorância de elementos relevantes para uma ideia, mas que dela ficaram alijados e desarticulados em determinado contexto. E isso ocorrerá quanto mais a estrutura física e psíquica de um homem for exígua.

Ora, uma constituição mental e corporal muito elementar também é associada "aos nossos primeiros anos de idade (ad nostrae priores aetatis annos)" quando, na proposição 32 de Ética III, se diz que o corpo das crianças está "como que num equilíbrio contínuo (veluti in aequilibrio continuo)". Já no escólio da proposição 39 de Etica $I V$, é dito que alguém que perdesse, por doença ou acidente, todo o patrimônio mental elaborado ao longo da vida, a ponto de perder inclusive o conhecimento da língua materna, poderia ser tido por um bebê adulto (pro infante adulto habere potuisset). Finalmente, no escólio da proposição 39 de Ética $V$, Espinosa é explícito a respeito dessa exiguidade infantil ao dizer que:

Aquele que (qui), como um bebê ou uma criança (ut infans vel puer) possui um corpo (corpus habet) apto a pouquíssimas [coisas] (ad paucissima aptum) e maximamente dependente de causa externas (et maxime pendens a causis externis), possui uma mente que (mentem habet quae) considerada sozinha em si mesma (in se sola considerata), quase não é consciente (nihil fere sit conscia) de si, nem de Deus nem das coisas (sui nec Dei nec rerum); e ao contrário (et contra) quem possui um corpo apto (qui corpus habet aptum) a muitas mais [coisas] (ad plurima) possui uma mente que (mentem habet quae) considerada sozinha em si mesma (in se sola considerata) é muito consciente (multum sit conscia) de si, de Deus e das coisas (sui et Dei et rerum). Nesta vida, portanto (In hac vita igitur) nos esforçamos primordialmente (apprime conamur) para que o corpo da infância (ut corpus infantiae) se mude (mutetur), o quanto sua natureza suporta e lhe convém (quantum ejus natura patitur eique conducit), em um outro (in aliud), que seja apto a muitas mais [coisas] (quod ad plurima aptum sit) e que se refira a uma mente que (quodque ad mentem referatur quae) seja consciente (sit conscia) de si de Deus e de muitas mais coisa (sui et Dei et rerum plurimum).

Mas, diante de tudo isso, o mais importante é considerarmos que, muito embora a criança seja evocada sempre que Espinosa quer indicar uma

Filosofia e Educação - ISSN 1984-9605 - Volume 5, Número 1

Abril - Setembro de 2013 
situação em que a simplicidade das construções perceptivas decorre apenas da escassez de percepções na mente e da exiguidade corporal, isso não pode indicar qualquer real imperfeição da condição infantil, uma vez que tal é sua própria natureza. Como ensina o escólio da proposição 6 de Ética $V$, ninguém se misera de um bebê (nemo miseretur infantis) pelo fato de que ele não sabe (propterea quòd nescit) falar, andar, raciocinar (loqui, ambulare, ratiocinari) e que, enfim, viva tantos anos (et quòd denique tot annos vivat) como que ínscio de si (quasi sui inscius). Aliás, o traço próprio do tipo da criança é justamente essa naturalidade de sua constituição: o recurso ao tipo intervém na argumentação precisamente para indicar que não se trata de uma situação anormal ou excepcional, isto é, excessivamente circunstanciada e, portanto, de validade restrita. $\mathrm{O}$ que é próprio às crianças diz respeito a todos os homens, ainda que, como se diz no escólio da proposição 39 de Ethica IV,

um homem de provecta idade (homo provectae aetatis) crê que a natureza destas [sc. das crianças] (credit naturam quorum) é tão diferente da sua (a sua tam diversam esse) que não poderia se persuadir (ut persuaderi non posset) de algum dia ter sido criança (se unquam infantem fuisse) se não fizesse (nisi faceret) a partir dos outros [homens] (ex aliis) uma conjectura acerca de si mesmo (de se conjecturam).

Ora, o trabalho da felicidade, no parágrafo 15 do Tratado da Eemenda, na modalidade específica da Doctrina de puerorum Educatione, depende, pois, desta compreensão de que será impossível a consecução do supremo conhecimento e do supremo bem se descuidarmos do fato de que todos começamos, na ordem do tempo, como crianças. Não cresceremos adquirindo uma natureza mais firme - e não ajudaremos ninguém a crescer simplesmente rejeitando as crianças que todos fomos e a exiguidade infantil em que, por vezes, nos reencontramos. Destarte, embora esse afazer pedagógico não tenha sido direta e detidamente desenvolvido por Espinosa, é possível afirmar - com base em uma análise do proêmio do Tratado da Emenda especialmente atenta ao conceito mesmo de emendatio - que o

Filosofia e Educação - ISSN 1984-9605 - Volume 5, Número 1

Abril - Setembro de 2013 
caráter ou espírito de doutrina espinosana da educação das crianças há de ser tal que deve necessariamente pautar-se pelo "princípio do acompanhamento do erro", exprimindo, também no âmbito da pedagogia, a perspectiva radicalmente imanentista do sistema de Espinosa. E era isso o que eu pretendia demonstrar.

\section{Referências bibliográficas}

ARIstóteles. Nichomachean Ethics in The Complete Works of Aristotle. Ed. J. Barnes. Princeton: Princeton University Press, 1995.

Chauí, M. A Nervura do Real. São Paulo: Companhia das Letras, 1999.

DJIN, H. D. The Way to Wisdom, Indiana: Purdue University Press, 1996.

EspinosA, B. Spinoza Opera. Im Auftrag der Heidelberger Akademie der Wissenschaft herausgegeben von Carl Gebhardt. Heidelberg: Carl Winters Universitätsbuchhandlung, 1972. 4 Vol.

- Traité de la Réforme de L'Entendement. Trad. introd e coment.: Bernard Rousset. Paris, Vrin, 1992.

- Tratado Breve. Traducción, prólogo y notas de Atilano Domínguez. Madrid. Alianza, 1990.

Tratado da Correção do intelecto in Col. Os Pensadores. Trad. E Notas:

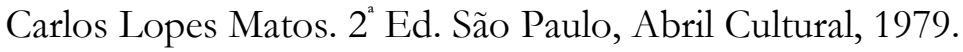

- Tratado da Reforma da Inteligência. Introdução, tradução e notas de Lívio Teixeira; São Paulo, Cia. Editora Nacional, 1966.

- Tratado Teológico-Político, Trad, introd e notas de Diogo Pires Aurélio. Lisboa, Imprensa Nacional-Casa da Moeda, 1988.

Heidegger, M. Ser e Tempo. Trad. Márcia de Sá Cavalcanti. Petrópolis: Vozes, 1988.

JAEgER, W. Paideia. São Paulo: Martins Fontes, 1979.

Jonchim, H. H. Spinosa's Tractatus de Intellectus Emendatione - A comentary. Oxford: Clarendon Press, 1958.

KanT, I. Lógica. Rio de Janeiro: Tempo Brasileiro, 1999.

Filosofia e Educação - ISSN 1984-9605 - Volume 5, Número 1

Abril - Setembro de 2013 
MATOS, C. L. Apontamentos datilografados para a preparação de sua tradução do Tractatus de Intellectus Emendatione. Mimeo, s/d.

MOREAU, P-F. Spinoza - L'expérience et l'éternité. Paris: PUF, 1994.

OliveirA, F. B. "A educação no Capítulo 9 do Apêndice da Ética IV de Espinosa" in Revista Sul-Americana de Filosofia e Educaşão - RESAFE. No. 17. Novembro/2011-Abril/2012.

REZENDE, C. N. "Os perigos da Razão segundo Espinosa" in Cadernos de História e Filosofia da Ciência. CLE-Unicamp. Campinas, Série 3, v. 14, n. 1, p. 59-118, jan.-jun. 2004.

"A Ordem que Naturalmente temos (ordem lógica e ordem histórica na metodologia espinosana)". In Cadernos Espinosanos (USP), v. 11, p. 93-110, 2004b.

"Saúde Mental Pública em Espinosa" in Invenções Democráticas A dimensão social da Saúde. Marcelo Justo (Org.). Belo Horizonte: Editora Autêntica, 2010.

- Ideia Verdadeira e História (em Espinosa). Cadernos Espinosanos (USP), São Paulo, v. 2, p. 103-134, 1997.

TEIXEIRA, L. A doutrina dos modos de percepção e o conceito de abstração na filosofia de Espinosa. São Paulo: Editora Unesp, 2001.

Tschirnhaus, E. W. Médecine de l'esprit ou préceptes généraux de l'art de découvrir. Introduction, traduction, notes et appendices par J. P. Wurtz. Paris, Éditions Ophrys, 1980.

ZWEERMAN, T. "L'indication d'une perspective philosophique dans l'introduction du Tractatus de Intellectus Emendatione", in Revue des sciences philosophiques et théologiques, No. 1, tome 71, pp. 77-94; Paris, Vrin, 1987. 